\title{
AN ANALYSE ON UNIVERSITY STUDENST WHO WORKS IN KARS CITY THE PROBLEM OF EMPLOYMENT UNEMPLOYMENT IN THE TERMS OF SOCIO-ECONOMIC DIMENSIONS
}

\author{
Ahmet DENIZ*, Ferhat DALBOY** \\ Kafkas Üniversitesi*; Kafkas Üniversitesi** \\ E-mail: ahmetdenizz@hotmail.com*; ferhatdalboy@hotmail.com** \\ Copyright (C) 2015 Ahmet DENIZ, Ferhat DALBOY. This is an open access article distributed \\ under the Eurasian Academy of Sciences License, which permits unrestricted use, \\ distribution, and reproduction in any medium, provided the original work is properly cited.
}

\begin{abstract}
The purpose of this research, creating an overall perspective on unemployment and employment situation in Turkey is investigating how gratifying working conditions in workplaces operating in theprovince of Kars. Therefore, the application is made to the Kafkas University poll workers had education students. The poll also satisfaction in the university and the city has tried to be measured. The results make the existing problems with the data obtained by determining a satisfying working life and university life during post-graduate residing in the province of Kars will remember with good feelings aimed to produce solutions to create a city. This study gives information about the general view of employment and unemployment in Turkey. And this study is prepared with the aim to produce some solutions could be made of the regulations as to what the working conditions for access to the advanced city level, considering their experience in Kars students will take place in the future labor market.
\end{abstract}

Keywords: Employment, unemployment, laborforce, labor market, Kars

\section{İstihdam ve İşsizlik Sorununun Sosyo-Ekonomik Bağlamında Kars İlinde Çalışan Üniversite Öğrencileri Üzerine Bir Analiz}

ÖZET: Bu araştırmanın amacı, Türkiye'deki işsizlik ve istihdam durumuna genel bir bakış açısı oluşturarak Kars ilinde faaliyet gösteren işyerlerinde çalışma koşullarının ne kadar memnuniyet verici olduğunun araştırılmasıdır. Bu sebeple Kafkas Üniversitesi'nde öğrenim görüp çalışan öğrencilere anket uygulaması yapılmıştır. Sunulan ankette ayrıca üniversite ve şehir memnuniyeti de ölçülmeye çalışılmıştır. Çalışma sonucunda edinilen verilerle var olan sorunlar belirlenerek çalışma yaşamını memnuniyet verici bir hale getirmek ve üniversite hayat1 boyunca Kars ilinde ikamet edenlerin mezuniyet sonrası güzel duygularla anımsayacağ 1 bir şehir yaratmak için çözüm önerileri üretmek hedeflenmiştir. Bu çalışma, Türkiye'de istihdam ve işsizliğin genel görünümü hakkında bilgi vermekte olup gelecekte işgücü piyasasında yer alacak öğrencilerin Kars ilindeki deneyimlerini göz önünde bulundurarak gelişmiş kentler seviyesine erişmek için çalışma koşullarında ne gibi düzenlemelerin yapılabileceği hususunda çözüm yolları üretebilmek amacı ile hazırlanmıştır. 
Anahtar Kelimeler: İstihdam, İşsizlik, İşgücü Piyasası, İşgücü Piyasası, Kars

\section{GİRIŞ}

Ele aldığımız çalışma Türkiye'de istihdam ve işsizlik olguları üzerine değerlendirmeler içermektedir. İstihdam edilenlerin çalıştığı işyerlerindeki memnuniyet durumu araştırılarak analize tabi tutulmuştur. En son olarak analiz sonuçları tartışılmış ve saptanan sorunlara yönelik çözüm önerileri üretmek amaçlanmıştır.

İşsiz geçen süreye karşı dayanma gücü azalan bireyin her koşul altında çalışmayı kabul etmesi işverenlerin bir takım zorunluluklardan kaçınmasına neden olmaktadır. Daha düşük ücret seviyesinde işçi çalıştırma, kaçak işçi çalıştırma (sigortasız veya göçmen işçi), çocuk işçi çalıştırma gibi yasadışı yollara yönelen işveren bu şekilde daha fazla kar kazanırken insan emeğinin değerini, insani onuru ve insan sağlığını da göz ardı edebilmektedir. Türkiye işgücü piyasası şartlarında halen birçok sektörde iş yeri güvenliği sağlanamamış ve işçi sağlığı tam olarak güvence altına alınamamıştır. Sağlıksız çalışma koşulları altında gerçekleşen işçi ölümleri ve sakatlanmalar bunun en önemli kanıtıdır. 2014 yılında Türkiye'de gözlenen iş kazası sonucu 1886 çalışanın hayatını kaybettiği görülmektedir (Sendika.org, E: 14.01.2015). Bunun yanında 2014 yılının ilk on ayında 235 kadın erkekler tarından öldürülmüştür (Kadına Şiddet E: 14.01.2014). Kadına yönelik şiddetin giderek farklı bir boyut kazandığı günümüzde çalışma hayatı içerisinde yer alan kadınlara yönelik fiziksel ve psikolojik tacizin bile bir türlü önüne geçilememiştir.

Türkiye genelinde istihdam ile işsizliğin genel görünümü, işsizlik ile mücadele yöntemleri, günümüzde iki haneli işsizlik yüzde oranlarına yükselmesi gibi sebepler çalışma amacına bizleri itmiştir. Kars ili hakkında genel bilgiler verilmeye çalışılmıştır. Kafkas Üniversitesi öğrencileri örneklem grubu olarak seçilmiştir. Örneklemi oluşturanlara demografik sorularla beraber Kars ilindeki çalışma koşullarına bakış açıları araştırılmış ve şehir, üniversite memnuniyet durumunu ölçmeye yönelik anket soruları sunulmuştur. Bu anket ile Kars ilinde çalışan öğrencilerin gözlemlemiş oldukları çalışma koşulları değerlendirmeye alınmak istenmiştir. Sorulan sorular SPSS programında analize tabi tutulmuştur. Elde edilen veriler doğrultusunda ortalamalara yönelik bir analiz yapılmıştır. Ortalama analize ek olarak cinsiyet, öğrenim durumu, çalışma yeri farklılıkları dikkate alınarak istihdam algısı incelenmiştir. Sonuç bölümünde ise memnuniyetsizliğin en fazla olduğu yani çalışan öğrencilerin en fazla şikâyetçi olduğu sorunların çözümüne yönelik çözüm öneriler sunulmuştur.

\section{KARS İLININ GENEL GÖRÜNÜMÜ}

\subsection{Kars İli Hakkında Tarihi Bilgi ve Coğrafik Konumu}

Şehre verilen isim Karsaklar adlı bir oymaktan gelmektedir. Kars adının kullanılmasının nedenine yönelik çeşitli söylemler bulunmaktadır. Bun söylemlerden biri de Kars adının, Kapı Kent anlamında kullanılan "Karis Kalaki” sözcügüünden türetilen biri isim olmasıdır. MisakMilli sınırlarında olup başka bir cumhuriyete başkentlik yapmış olması da önemli bir özelliktir. Kars ve çevresi geçmiş yıllarda Urartu, Sasani, ve Pers egemenliği altında kalmıştır. Bölge Yavuz Sultan Selim tarafından Osmanlı topraklarına katılmıştır. Sovyet Rusya ile 
imzalanan Moskova Antlaşması neticesinde Kars ve Artvin'in Rusya ile sınırı belirlenerek TBMM hükümetinin kurulmasıyla sınırlar kesinlik kazanmıştır (TUİK, www.tuik.gov.tr, E: 16.06.2013).

Ardahan, Erzurum, Ağrı, Iğdır illeri ile sınır komşusudur. Ayrıca Ermenisitan ile de komşuluk durumu bulunmaktadır. Etrafi dağlarla çevrili bir plato özelliği gösteren Kars ili deniz seviyesinde 1768 metre yüksekliktedir. Sahip olduğu yüz ölçümünün \%51'ini platolar oluştururken ova büyüklüğü bakımından Doğu Anadolu da birinci sıradadır. Aras Nehri, Arpaçay ve Kars Çayları önemli akarsularıdır. Arpaçay’ın bir önemli özelliği ise doğuda Ermenistan ile sınır oluşturmasıdır. Belli başlı göller ise Çıldır, Aygır, Çengilli, Kuyucak ve Turna Gölleridir. Ayrıca yapay göl olarak Arpaçay Baraj gölünün varlığı söz konusudur. Kış şartlarının oldukça sert geçtiği şehirde kış turizmi gelişme göstermektedir. İklime bağlı olarak şekillenen bitki örtüsü step halindedir. İl toprakların büyük bir bölümü çayır ve hayvancılığın yapıldığı meralardan oluşmaktadır. Orman alanı bakımından ise fazlaca yetersizlik görülmektedir (SERKA, 2008: s. 11,13). Kars şehri, Anadolu ve Asya toprakları arasında bulunan bir mevki üzerinde yer almaktadır. Türkiye'nin Kafkasya açılan bir kapısı konumunda bulunan Kars, Çin'den gelen İpek Yolunun son bulduğu yerdir. Şehir ulaşımı hava, kara, demir yolları ile gerçekleştirilmektedir. Karadeniz illerine yönelik ulaşım ise Ardahan ve Göle üzerinden yapılmaktadır (Kars Valiliği, www.kars.gov.tr, E: 16.06.2013).

\subsection{Kars İlinin Ekonomik Yapısı}

\subsubsection{Tarım}

Temel olarak kuru tarım yöntemiyle buğday, arpa, korunga, yonca ve fĭg üretimi yapılmaktadır. Endüstriyel olarak ise patates ve şeker pancarı üretimi gerçekleştirilmektedir. Geçim kaynağının temeli tarım ve hayvancılık faaliyetleri oluşturmaktadır. Bu oran Türkiye ve Doğu Anadolu Bölgesi ortalamalarının üzerindedir. Temel geçim kaynağına yönelik son yıllarda araç gereç sayısında artış gözlenmektedir (Kars Valiliği, www.kars.gov.tr, E: 17.06.2013).

\subsubsection{Hayvancilık}

Kars, Türkiye ve çevre ülkeler için oldukça önemli bir hayvancılık merkezidir. Doğal şartların tarımı kısıtlaması ve sanayi kalkınma durumunun düşük olması insanları hayvancılık konusunda uzmanlaşmaya itmiştir. Hayvancılık sektörü Kars ilinde ticaretten çok temel tüketim mallarının tedarikine yönelik olarak gerçekleşmektedir. Fakat özellikle Kurban Bayramı öncesi şehir dışına çok sayıda hayvan ihracının olduğu da bir gerçektir. Son dönemlerde özellikle Serhat Kalkınma Ajansı, Tarımsal ve Kırsal Kalkınmayı Destekleme Kurumu ve benzer kuruluşların faaliyeti sonucunda hayvan ticaretine yönelik cazibe artış1 yaşanmaktadır. Bu destekler hayvancılık sektöründe ticari faaliyet gelişimini arttırmaktadır (Baki, 2008: s. 30).

\subsubsection{Sanayi}

Ham maddeye ve tüketim merkezine olan uzaklık, sermaye birikiminin az oluşu, Karsta sanayi sektörünün gelişemediğini söylemek mümkündür. Fabrikasyonun bu alanda gözlenmesi hammadde olarak toprak ve ayakkabı imalatında kullanılan hayvan derisinin bolluğuna bağlanmaktadır. Şehirde var olan küçük sanayi iletmeleri önceleri göl yeri mevkii olarak anılan yerde faaliyet gösterirken OSB'nin kurulmasıyla buraya taşınmıştır (Kars İli Çevre Durum Raporu, 2011: s. 198). Bakanlar kurulu tarafından 1975 yılında alınan bir karar 
ile kalkınmanın dengeli olarak gerçekleşmesi amacıyla OSB'nin kurulması kararlaştırılmıştır. Paşaçayır mevkiinde yer alan organize sanayi bölgesi şehir merkezine $15 \mathrm{~km}$ uzaklıktadır (SERKA, http://www.serka.org.tr/kars.asp, E: 19.06.2013). Sanayi ve Ticaret İl Müdürlüğü verileri vasıtasıyla hazırlanan tablodan yararlanmak faydalı olacaktır. Tabloda OSB içerisinde faaliyet gösteren firmalar ve çalışma kolları gösterilmektedir.

Tablo 1: Kars Organize Sanayi Bölgesinde (OSB) Yer Alan İşletmeler

\begin{tabular}{|l|c|l|l|}
\hline Firma Durumu & $\begin{array}{c}\text { Firma } \\
\text { Sayısı }\end{array}$ & Faaliyet Alanı & $\begin{array}{c}\text { Firma } \\
\text { Sayısı }\end{array}$ \\
\hline Tahsis Yapılan Firma & 86 & Süt ve Süt Ürünleri & 22 \\
\hline Üretimdeki Firma & 45 & Orman ve Orman Ürünleri & 5 \\
\hline Kapalı Firma & 0 & Tarımsal makine ve malzeme & 1 \\
\hline Proje Safhasındaki Firma & 12 & Taş Kesme & 1 \\
\hline İnşaat Halindeki Firma & 16 & Hazır Beton ve Kum Eleme & 7 \\
\hline Diğer & & $\begin{array}{l}\text { (Unlu mamül, et ürünleri, 1sı yalıtım, karo imalatı, } \\
\text { temizlik ürünleri, gida imalat, karma yem, kağıt havlu- } \\
\text { peçete, kilit parke taşı, metal rekor, çevre hizmetleri, } \\
\text { TÜVTURK araç muayene istasyonu) }\end{array}$ & \\
\hline
\end{tabular}

Kaynak: http://www.karsosb.org.tr/kars-osb/kars-osb-kapasite-durumu.html (E: 11.09.2014)

\subsubsection{Turizim}

Türkiye'nin en yüksek bölgesinde bulunan Kars ili bulunduğu yükseklik ve doğa şartları bakımından kış turizminin gelişmesine elverişlidir. Bu bakımdan Kış turizm potansiyelinin yüksek olduğu iller arasında yer almaktadır. Kars ili Sarıkamış ilçesinde yer turistik oteller ve kayak tesisleri bakımından oldukça önemlidir. Ayrıca köklü bir tarihi mirasa sahip olması bakımından kültür turizmi açısından potansiyeli yüksek bir şehirdir. Bu bakımdan Ani Antik Kenti, tarihi Rus, Ermeni ve Malakan evleri turistik açıdan oldukça ilgi çekicidir (Kars İl Kültür ve Turizm Müdürlügü, www.karskulturturizm.gov.tr, E: 20.06.2013). Bu konuda Kültür ve Turizm Bakanlığının yürütücü olduğu birçok ev restorasyonı edilmiştir. Ayrıca kültürel turizme katkı sağlayan Beylerbeyi Sarayı, Ejderha Kulesi, Manuçehr Camii, Evliya Camii, İlbeyoğlu Hamamı, Mazlumağa Hamamı, Kars Kalesi ve tarihi Taş Köprü gibi tarihi eserler bulunmaktadır (SERKA, www.serka.gov.tr, E: 02.12.2014).

Tablo 2: Turizm İşletme Belgeli Tesislerde Konaklayan Turist Sayıları

\begin{tabular}{|l|l|l|l|}
\hline & $\mathbf{2 0 1 0}$ (Bin Kişi) & $\mathbf{2 0 1 1}$ (10Aylık) (Bin Kişi) & Toplam \\
\hline Yerli & 51066 & 57705 & 108771 \\
\hline Yabancı & 13523 & 24513 & 38036 \\
\hline Toplam & 64589 & 82218 & \\
\hline
\end{tabular}

Kaynak: Kars ìl Kültür ve Turizm Müdürlügü, http://www.karskulturturizm.gov.tr/belge/190806/istatistikler.html (E: 24.11.2014) 


\subsubsection{Ticaret}

Kars ilinde ticarete konu olan materyaller genellikle tarım ve hayvancılık sektörünün etkisiyle şekillenmektedir. İl içi ticaret genellikle küçük esnaf teşekkülleri vasıtasıyla gerçekleşmektedir. Bu bağlamda ticari sektör içerinde yer alan çalışanların ve esnafların düşük gelirlerle sigortasız olarak çalıştığı görülmektedir. Hayvan ticaretinin hız kazandığ1 dönemler ise şehir içi ve şehir dışı sevkiyatın kolaylaştığı yaz dönemleridir. Bölgesel kalkınma bakımından ve ihtiyaç duyulan malların şehir içinde üretilememesi sebebiyle ihtiyaç duyulan ürünler genellikle başka şehirlerden tedarik edilmektedir (Baki, 2008: s. 47).

\section{ARAŞTIRMA YÖNTEMI}

\subsection{Araştırmanın Tasarımı}

Saha araştırmasına dayanan bu çalışmanın metodolojisi; araştırmanın amacı, önemi, kapsamı ve sınırları gibi başlıklar altında incelenmektedir.

\subsection{Araştırmanın Amacı ve Önemi}

Araştırmamızın genel amacı; Kars ilinde çalışan üniversite öğrencilerinin isşgücü piyasasından ve çalışma ortamlarında kendilerine sunulan firsatlardan memnun olma algısının ortaya konulmasidir.

Araştırmanın önemi; İstihdam koşullarında karşılaşılan zorlukların belirlenmesi açısından önem taşıyan bu çalışma, işverenleri ve işgücü piyasası denetimi yapan yetkileri bilgilendirme, tespit edilen yetersizliklerin giderilebilmesi için alınabilecek önlemlerin belirlenmesi bakımında da yol gösterici niteliktedir.

\subsection{Araştırmanın Kapsamı, Sınırları ve Kısıtları}

Araştırma Kars ilinde çalışan Kafkas Üniversitesi öğrencilerini kapsamaktadır. Bu kapsam Kars ilinde çalışan öğrenci mevcudu dikkate alınarak belirlenmiştir. Bu sebeple araştırmanın evrenini Kafkas Üniversitesi öğrencileri oluşturmaktadır. Araştırmanın sınırları ve kısıtları ise aşağıda sıralanmaktadır.

Araştırmanın uygulanacă̆ evren ve örnekleme ilişkin sınırlılık ve kısıtlılık: Sadece çalışan öğrencilerin düşüncelerine başvurulmuştur.

* Veri Toplama Araçlarına Yönelik Sinırlılık ve Kısıtlılık: Araştırmada veri toplama aracı olarak anket tekniği kullanılmıştır.

\subsection{Araştırmanın Hipotezleri}

Araştırma modeline uygun olarak üç temel hipotez gerçekleştirilmiştir. Söz konusu hipotezleri aşağıdaki gibi belirtmek mümkündür. 
H1: Öğrencilerin cinsiyete göre Kars'taki istihdam algısında fark yoktur.

H2: Öğrencilerin öğrenim türüne göre Kars’taki istihdam algısında fark yoktur.

H3: Öğrencilerin çalışma yerine göre Kars’taki istihdam algısında fark vardır.

\subsection{Araştırmanın Yöntemi}

$\mathrm{Bu}$ araştırma anket yöntemi ile veri toplanması ve analiz edilmesine yönelik bir saha çalışması olarak tasarlanmıştır. Araştırmada tümevarım yöntemi kullanılmıştır.

\section{6. Örnekleme Süreci}

Araştırmanın evrenini Kafkas Üniversitesi öğrencileri olarak yaklaşık 15.000 oluşturmaktadır. Belirtilen evreni temsil edecek düzeyde kolayda örnekleme yoluyla 391 gözleme ulaşılmıştır. $\mathrm{Bu}$ örnek, \%95 güvenirlik seviyesinde homojen bir evreni temsil edecek niteliktedir (Altunış1k vd., 2010: s.135).

Tablo 3: Araştırmanın Örneklemi

\begin{tabular}{|l|l|l|l|}
\hline \multicolumn{1}{|c|}{ Anketin Kapsamı } & Evren & Gerekli Örneklem & Ulaşılan Örneklem \\
\hline Kafkas & 15.000 ve üzeri & 381 & 391 \\
Üniversitesi & & & \\
Öğrencileri & & & \\
\hline
\end{tabular}

\subsection{Veri Toplama Yöntem ve Aracı}

Araştırma tanımlayıcı nitelikte oluşturularak verilerin toplanması için anket tekniği kullanılmıştır. Anket oluşturulurken çalışan öğrencilerin düşüncelleri doğrultusunda işyerlerinde karşılaşabilecekleri sorunlar dikkate alınarak hazırlanmıştır. Pilot bir uygulamanın ardından uzman görüşü alınarak soruların bir kısmında değişiklik yapılmış bazı sorular çıkarılmış ve yeni sorularda eklenerek anketin son halini alması sağlanmıştır.

\subsection{Verilerin Analizi ve Değerlendirilmesi}

Verilerin analiz edilmesinde SPSS (Statistical Package for Social Sciences) 19.0 programı kullanılmıştır. Elde edilen verilerin ortalamalarına ilaveten istatistiki analiz olarak t testi ve anova testi ile de istihdam algısı araştırılmaya çalışılmıştır. İstihdam algısındaki farklılığın analizi için $t$ testi ve anova testi uygulanmıştır.

\subsection{Demografik Özellikler}

Yapılan araştırmaya toplam 391 kişi katılmıştır. Araştırmaya katılanların \%52,9 (207 kişi)'u erkek iken \%47,1 (184 kişi)'i bayandır. Araştırmaya katılanların \%27,1 (106 kişi)'i 15-20 yaş 
arası, \%54,2 (212 kişi)'si 21-25 yaş arası, \%12,5 (49 kişi)'i 26-30 yaş arası, \%3,1 (12 kişi)'i 31-35 yaş arası ve \%3,1 (12 kişi)'i 36 ve üstü yaştadır. Araştırmaya katılanların \%14,6 (57 kişi)'s1 1 yıldan az, \%16,9 (66 kişi)'u 2 yı1, \%15,3 (60 kişi)'ü 3 yı1, \%21,2 (83 kişi)'si 4 yıl ve $\% 32,0$ (125 kişi)'1 5 yıl ve daha fazla süre ile Kars’ta bulunmaktadır.

Katılılımcıların \%38,1 (149 kişi)'i İ̈BF, \%9,2 (36 kişi)'si Fen Edebiyat Fakültesi, \%10,0 (39 kişi)'^1 Kazım Karabekir MYO, \%15,3 (60 kişi)'ü Eğitim Fakültesi, \%6,6 (26 kişi)'sı Atatürk SMYO, \%6,6 (26 kişi)'sı Veteriner Fakültesi, \%6,1 (24 kişi)'i ve \%7,9 (31 kişi)'u Formasyon öğrencileridir. Araştırmaya katılanların \%58,3 (228 kişi)'ü Normal Öğretim, \%41,7 (163 kişi)'si İkinci Öğretim öğrencisidir.

Katılımcıların \%26,3 (103 kişi)'ü 1000 TL'den az, \%30,2 (118 kişi)'si 1001-1500 TL arası, \%17,9 (70 kişi)'u 15001-2000 TL arası, \%16,1 (63 kişi)'i 2001-2500 TL arası, \%4,9 (19 kişi)'u 2501-3000TL arası, \%4,6 (18 kişi)'s 3001 TL ve üzerinde aile aylık gelirine sahiptir.

Araştırmaya katılanların \%54,2 (212 kişi)'si 500 TL'den az, \%33,8 (132 kişi)'i 500-1000 TL arası, \%5,4 (21kişi)'ü 1001-1500 TL arası ve \%6,6 (26 kişi)'sı 1500 TL'den fazla aylık harcama yapmaktadır. Katılımcıların \%56,5 (221 kişi)'i 500 TL'den az, \%29,7 (116 kişi)'si 500-1000 TL arası, \%7,4 (29 kişi)'ü 1001-1500 TL arası ve \%6,4 (25 kişi)'ü 1500 TL'den fazla aylık gelire sahiptir.

Kafkas Üniversitesinde okuyan ve daha önce herhangi bir sebepten Kara ilinde çalışanlara yönelik olduğundan, çalışmayan öğrencilerin anketleri uygulamadan çıkarılmıştır. Araştırmaya katılanların hepsi \%100,0 (391 kişi)'ü daha önce Kars ilinde bir işyerinde çalışmış veya çalışmaktadır. Katılılmcıların \%73,4 (287 kişi)'ü Özel, \%13,8 (54 kişi)'i Kamu, \%12,8 (50 kişi)'i Üniversitede (Yarı zamanlı) çalışmaktadır.

\subsection{Kars'taki İstihdam Algısı}

Kars ilinde çalışan öğrencilerin Kars ilindeki istihdam ve işsizlik durumuna bakışını belirlemek üzere sorulan sorulara verilen cevaplar ayrı ayrı ve bir bütün halinde aşağıda gösterilmiştir. Tabloya göre Kars Kafkas üniversitesi öğrencileri tarafından istihdam koşulları ile ilgili önemli görülen ilk üç ifade şunlardır.

$>$ Kars'taki işyerlerinde fiziksel taciz söz konusudur $(3,63)$,

$>$ Kars'taki işyerlerinde psikolojik taciz söz konusudur $(3,28)$

$>$ Kars'taki işyerlerinde ortaya çıkan zararlar çalışan ücretlerine yansıtılmaktadır $(3,17)$

Tabloya göre Kars Kafkas üniversitesi öğrencileri tarafından istihdam koşulları ile ilgili yetersiz görülen ilk üç ifade şunlardır.

> Kars'taki işyerlerinde çalışanlara çeşitli kariyer firsatları sunulmaktadır $(2,27)$

$>$ Kars'taki işyerlerinde yasalara uygun olarak engelli hareket alanı sağlanmıştır $(2,37)$

$>$ Kars'taki işyerlerinde çalışanlara fazla mesai ödemeleri yapılır $(2,39)$ 
Tablo 4: Tanımlayıcı İstatistiklerin Tümü

\begin{tabular}{|c|c|c|c|c|c|}
\hline İFADELER & $\mathrm{N}$ & En az & $\begin{array}{c}\text { En } \\
\text { Fazla }\end{array}$ & Ortalama & \begin{tabular}{|l} 
Standart \\
Sapma
\end{tabular} \\
\hline Diğer çalışanların davranışı rahatsızlık vericidir. & 391 & 1 & 5 & 2,75 & 1,283 \\
\hline Müşterilerin davranışları rahatsızlık vericidir. & 391 & 1 & 5 & 2,88 & 1,176 \\
\hline Çalışanların ücreti zamanında ödenmektedir. & 391 & 1 & 5 & 3,02 & 1,239 \\
\hline Ödenen ücret seviyesi yeterli düzeydedir. & 391 & 1 & 5 & 2,40 & 1,244 \\
\hline İşyerleri, iş sağlığı ve güvenliği bakımından uygundur. & 391 & 1 & 5 & 2,52 & 1,174 \\
\hline İşyerleri hijyen bakımından uygundur. & 391 & 1 & 5 & 2,51 & 1,132 \\
\hline Gerekli sosyal haklar sunulur (yemek,servis vb...) & 391 & 1 & 5 & 2,55 & 1,190 \\
\hline Tütün ve alkol yasağına riayet edilir. & 391 & 1 & 5 & 2,89 & 1,269 \\
\hline Genel ahlaka ve adaba uygun işler yapılır. & 391 & 1 & 5 & 2,98 & 1,198 \\
\hline Fazla mesailerde ek ödeme yapılır. & 391 & 1 & 5 & $\underline{2,39}$ & 1,160 \\
\hline SGK primi yatırılmaktadır. & 391 & 1 & 5 & 2,57 & 1,228 \\
\hline İşten çıkış anları güvenli saatlere denk gelmektedir & 391 & 1 & 5 & 2,73 & 1,182 \\
\hline Bayan istihdamına yönelik hoşgörü vardır. & 391 & 1 & 5 & 2,81 & 1,258 \\
\hline Ödenen ücret asgari seviyededir (Asgari ücret ödemesi) & 391 & 1 & 5 & 2,63 & 1,278 \\
\hline Fiziksel taciz söz konusudur. & 391 & 1 & 5 & 3,63 & 1,200 \\
\hline Psikolojik taciz söz konusudur. & 391 & 1 & 5 & 3,28 & 1,285 \\
\hline Giyim, kuşam eleştiri konusu olabilmektedir. & 391 & 1 & 5 & 2,91 & 1,319 \\
\hline İşin yapılması için gereken ekipmanlar yeterlidir. & 391 & 1 & 5 & 2,64 & 1,132 \\
\hline Zararlar çalışan ücretlerine yansıtılmaktadır. & 391 & 1 & 5 & 3,17 & 1,175 \\
\hline İşe alım ve işten çıkarma süreci yasalara uygun yürütülür. & 391 & 1 & 5 & 2,44 & 1,207 \\
\hline Çocuk işçi çalıştırma durumu gözlenmektedir. & 391 & 1 & 5 & 3,13 & 1,284 \\
\hline Engelli personel istihdamı yapılmaktadır. & 391 & 1 & 5 & 2,48 & 1,141 \\
\hline Engelliler için uygun hareket alanları yapılmıştır. & 391 & 1 & 5 & $\underline{2,37}$ & 1,092 \\
\hline Çalışanların düşünce ve önerilerine değer verilmektedir. & 391 & 1 & 5 & 2,54 & 1,140 \\
\hline Çalışanlara çeşitli kariyer imkanları sunulmaktadır. & 391 & 1 & 5 & $\underline{2,27}$ & 1,086 \\
\hline Çalışanlara gerekli iş yeri eğitimi verilmektedir. & 391 & 1 & 5 & 2,42 & 1,149 \\
\hline İŞKUR istihdam konusunda yardımcı olmaktadır. & 391 & 1 & 5 & 2,82 & 1,207 \\
\hline İŞKUR ihtiyaç duyulan elemanın teminini sağlamaktadır & 391 & 1 & 5 & 2,71 & 1,213 \\
\hline
\end{tabular}

\subsection{Kars’taki İstihdam Algısına Yönelik Soruların Değerlendirilmesi}

Kars Kafkas üniversitesi öğrencileri tarafından istihdam ve işsizlikle ilgili her bir soruya verdikleri cevaplar aşağıda gösterilmektedir.

"Kars'taki işyerlerinde diğer çalışanların davranışları rahatsızlık vericidir" şeklindeki 11. soruya katılımcıların \%11,0 (43 kişi)'i dolayısıyla en az oranı kesinlikle katılıyorum demiştir. Çalışanın, çalışandan rahatsız olması dikkat çekcidir. 


\begin{tabular}{|l|l|l|l|}
\hline \multicolumn{4}{|c|}{ Tablo 5: Diğer Çalışanların Davranışları } \\
\hline & $\mathrm{N}$ & Geçerli Yüzde & Kümülatif Yüzde \\
\hline KESINLIKKLE KATILMIYORUM & 86 & 22,0 & 22,0 \\
\hline KATILMIYORUM & 80 & 20,5 & 42,5 \\
\hline KISMEN KATILIYORUM & 112 & 28,6 & 71,1 \\
\hline KATILIYORUM & 70 & 17,9 & 89,0 \\
\hline KESINLIKKLE KATILIYORUM & 43 & $\mathbf{1 1 , 0}$ & 100,0 \\
\hline TOPLAM & 391 & 100,0 & \\
\hline
\end{tabular}

"Kars’taki işyerlerinde müşterilerin davranışları rahatsızlık vericidir" şeklindeki 12. soruya katılımcıların \%7,4'ü (29 kişi) yani en az oranı kesinlikle katılıyorum şeklinde cevap vermiştir.

\begin{tabular}{|l|l|l|l|}
\hline \multicolumn{4}{|c|}{ Tablo 6: Müşterilerin Davranışları } \\
\hline & $\mathrm{N}$ & Geçerli Yüzde & Kümülatif Yüzde \\
\hline KESINLLIKLE KATILMIYORUM & 68 & 17,4 & 17,4 \\
\hline KATILMIYORUM & 63 & 16,1 & 33,5 \\
\hline KISMEN KATILIYORUM & 137 & 35,0 & 68,5 \\
\hline KATILIYORUM & 94 & 24,0 & 92,6 \\
\hline KESİNLIKLLE KATILIYORUM & 29 & 7,4 & 100,0 \\
\hline TOPLAM & 391 & 100,0 & \\
\hline
\end{tabular}

"Kars'taki işyerlerinde çalışanların ücreti zamanında ödenmektedir" şeklindeki 13. soruya katılımcıların \%13,6’sı (53 kişi) kesinlikle katılmıyorum diye cevap vermiştir.

\begin{tabular}{|c|c|c|c|}
\hline \multicolumn{4}{|c|}{ Tablo 7: Ücretin Zamanında Ödenmesi } \\
\hline & $\mathrm{N}$ & Geçerli Yüzde & Yüzde \\
\hline KESINLülatif \\
\hline KATILMIYORUM & 53 & 13,6 & 13,6 \\
\hline KATILMIYORUM & 82 & 21,0 & 34,5 \\
\hline KISMEN KATILIYORUM & 113 & 28,9 & 63,4 \\
\hline KATILIYORUM & 89 & 22,8 & 86,2 \\
\hline KESINLIKLE KATILIYORUM & 54 & 13,8 & 100,0 \\
\hline TOPLAM & 391 & 100,0 & \\
\hline
\end{tabular}

"Kars'taki işyerlerinde ödenen ücret seviyesi yeterlidir" şeklindeki 14. soruya katılımcıların \%58,3’ü (228 kişi) yani çoğunluğu katılmıyorum şeklinde cevap vermiştir.

\begin{tabular}{|l|l|l|l|}
\hline \multicolumn{4}{|c|}{ Tablo 8: Ücret Seviyesinin Yeterliliği } \\
\hline & N & Geçerli Yüzde & Kümülatif Yüzde \\
\hline KESINLIKLE KATILMIYORUM & 115 & $\mathbf{2 9 , 4}$ & 29,4 \\
\hline KATILMIYORUM & 113 & $\mathbf{2 8 , 9}$ & 58,3 \\
\hline KISMEN KATILIYORUM & 85 & 21,7 & 80,1 \\
\hline KATILIYORUM & 47 & 12,0 & 92,1 \\
\hline
\end{tabular}




\begin{tabular}{|l|l|l|l|}
\hline KESINLIKLE KATILIYORUM & 31 & 7,9 & 100,0 \\
\hline TOPLAM & 391 & 100,0 & \\
\hline
\end{tabular}

“Kars’taki işyerleri iş güvenliği ve iş sağlı̆̆ bakımından yeterince güvenlidir” şeklindeki 15 . soruya katılımcıların \%32,5'i (127 kişi) yani en fazla oranı katılmıyorum şeklinde cevap vermiştir.

\begin{tabular}{|l|l|l|l|}
\hline \multicolumn{4}{|c|}{ Tablo 9: İş Güvenliği ve Sağlığı Bakımından Yeterlilik } \\
\hline & $\mathrm{N}$ & Geçerli Yüzde & Kümülatif Yüzde \\
\hline KESINLIKLE KATILMIYORUM & 84 & 21,5 & 21,5 \\
\hline KATILMIYORUM & 127 & $\mathbf{3 2 , 5}$ & 54,0 \\
\hline KISMEN KATILIYORUM & 104 & 26,6 & 80,6 \\
\hline KATILIYORUM & 46 & 11,8 & 92,3 \\
\hline KESINNLIKLE KATILIYORUM & 30 & 7,7 & 100,0 \\
\hline TOPLAM & 391 & 100,0 & \\
\hline
\end{tabular}

"Kars’taki işyerleri hijyen bakımından gerekli uygunluğa sahiptir” şeklindeki 16. soruya katılımcıların \%31,7'si (124 kişi) dolayısıyla çoğunluğu katılmıyorum şeklinde cevap vermiştir.

\begin{tabular}{|l|l|l|l|}
\hline \multicolumn{5}{|c|}{ Tablo 10: İşyeri Hijyeni } & N & Geçerli Yüzde & Kümülatif Yüzde \\
\hline & 82 & 21,0 & 21,0 \\
\hline KESINLIKKLE KATILMIYORUM & 124 & $\mathbf{3 1 , 7}$ & 52,7 \\
\hline KATILMIYORUM & 108 & 27,6 & 80,3 \\
\hline KISMEN KATILIYORUM & 56 & 14,3 & 94,6 \\
\hline KATILIYORUM & 21 & 5,4 & 100,0 \\
\hline KESINNLIKKLE KATILIYORUM & 391 & 100,0 & \\
\hline TOPLAM & & \\
\hline
\end{tabular}

"Sosyal haklar sunulmaktadır" şeklindeki 17. soruya katılımcıların \%28,1'si (110 kişi) dolayısıyla çoğunluğu katılmıyorum şeklinde cevap vermiştir.

\begin{tabular}{|l|l|l|l|}
\hline \multicolumn{4}{|c|}{ Tablo 11: Gerekli Sosyal Hakların Sunulması } \\
\hline \multicolumn{2}{|l|}{ N } & Geçerli Yüzde & Kümülatif Yüzde \\
\hline KESINLIKLE KATILMIYORUM & 88 & 22,5 & 22,5 \\
\hline KATILMIYORUM & 110 & 28,1 & 50,6 \\
\hline KISMEN KATILIYORUM & 111 & 28,4 & 79,0 \\
\hline KATILIYORUM & 53 & 13,6 & 92,6 \\
\hline KESINLIKKLE KATILIYORUM & 29 & 7,4 & 100,0 \\
\hline TOPLAM & 391 & 100,0 & \\
\hline
\end{tabular}

"Kars'taki işyerlerinde tütün yasağ 1 ve alkol yasağ 1 uygulamalarına uyulmaktadır" şeklindeki 18. soruya katılımcıların \%23,5’i (92 kişi) katılıyorum şeklinde cevap vermiştir.

Tablo 12: Kanuni Kisitlamalara Uyum 
İstihdam ve İşsizlik Sorununun Sosyo-Ekonomik Bağlamında Kars İlinde Çalışan Üniversite Öğrencileri Üzerine Bir Analiz

\begin{tabular}{|l|l|l|l|}
\hline & N & Geçerli Yüzde & Kümülatif Yüzde \\
\hline KESINLIKLE KATILMIYORUM & 77 & 19,7 & 19,7 \\
\hline KATILMIYORUM & 65 & 16,6 & 36,3 \\
\hline KISMEN KATILIYORUM & 115 & 29,4 & 65,7 \\
\hline KATILIYORUM & 92 & $\mathbf{2 3 , 5}$ & 89,3 \\
\hline KESINLIKKLE KATILIYORUM & 42 & 10,7 & 100,0 \\
\hline TOPLAM & 391 & 100,0 & \\
\hline
\end{tabular}

"Kars’taki işyerlerinde genel ahlaka ve adaba uygun faaliyet gösterilir" şeklindeki 19. soruya katılımcıların \%26,6’sı (104 kişi) katılıyorum şeklinde cevap vermiştir.

\begin{tabular}{|l|l|l|l|}
\hline \multicolumn{4}{|c|}{ Tablo 13: Genel Adaba ve Ahlaka Uygunluk } \\
\hline & $\mathrm{N}$ & Geçerli Yüzde & Kümülatif Yüzde \\
\hline KESINLIKLE KATILMIYORUM & 62 & 15,9 & 15,9 \\
\hline KATILMIYORUM & 60 & 15,3 & 31,2 \\
\hline KISMEN KATILIYORUM & 128 & 32,7 & 63,9 \\
\hline KATILIYORUM & 104 & $\mathbf{2 6 , 6}$ & 90,5 \\
\hline KESINLIKLE KATILIYORUM & 37 & 9,5 & 100,0 \\
\hline TOPLAM & 391 & 100,0 & \\
\hline
\end{tabular}

"Kars’taki işyerlerinde çalışanlara fazla mesai ödemesi yapılmaktadır” şeklindeki 20. soruya katılımcıların \%28,6'sı (112 kişi) kesinlikle katılmıyorum şeklinde cevap vermiştir.

\begin{tabular}{|l|l|l|l|}
\hline \multicolumn{4}{|c|}{ Tablo 14: Fazla Mesai Ödemesi } \\
\hline & $\mathrm{N}$ & Geçerli Yüzde & Kümülatif Yüzde \\
\hline KESINLIKLE KATILMIYORUM & 112 & $\mathbf{2 8 , 6}$ & 28,6 \\
\hline KATILMIYORUM & 97 & 24,8 & 53,5 \\
\hline KISMEN KATILIYORUM & 120 & 30,7 & 84,1 \\
\hline KATILIYORUM & 41 & 10,5 & 94,6 \\
\hline KESINLIKKLE KATILIYORUM & 21 & 5,4 & 100,0 \\
\hline TOPLAM & 391 & 100,0 & \\
\hline
\end{tabular}

“Kars’taki işyerlerinde işveren çalışma süresi boyunca SGK primini yatırmaktadır” şeklindeki 21. soruya katılımcıların \%24,8'i (97 kişi) katılmıyorum şeklinde cevap vermiştir. Çalışan öğrencilerin yarı zamanlı olması SGK primlerin yatırılmasında ciddiyetsiz davranıldığını göstermektedir. Halbuki yasal düzenlemede yarı zamanlıda olsa pirim yatırılmasını emretmektedir.

\begin{tabular}{|l|c|c|c|}
\hline \multicolumn{4}{|c|}{ Tablo 15: SGK Priminin Yatırılmas1 } \\
\hline & $\mathrm{N}$ & Geçerli Yüzde & Kümülatif Yüzde \\
\hline KESİNLIKLE KATILMIYORUM & 97 & $\mathbf{2 4 , 8}$ & 24,8 \\
\hline KATILMIYORUM & 92 & 23,5 & 48,3 \\
\hline KISMEN KATILIYORUM & 115 & 29,4 & 77,7 \\
\hline KATILIYORUM & 56 & 14,3 & 92,1 \\
\hline
\end{tabular}




\begin{tabular}{|l|l|l|l|}
\hline KESINLIKLE KATILIYORUM & 31 & 7,9 & 100,0 \\
\hline TOPLAM & 391 & 100,0 & \\
\hline
\end{tabular}

"Kars’ta işten çıkış saatleri güvenliği tehdit etmeyecek saatlere denk gelmektedir" şeklindeki 22. soruya katılımcıların \%24,8’i (97 kişi) katılmıyorum şeklinde cevap vermiştir.

\begin{tabular}{|l|l|l|l|}
\hline \multicolumn{5}{|c|}{ Tablo 16: İşten Çıkış Saatlerinin Uygunluğu } \\
\hline & $\mathrm{N}$ & Geçerli Yüzde & Kümülatif Yüzde \\
\hline KESINLIKKLE KATILMIYORUM & 70 & 17,9 & 17,9 \\
\hline KATILMIYORUM & 97 & $\mathbf{2 4 , 8}$ & 42,7 \\
\hline KISMEN KATILIYORUM & 126 & 32,2 & 74,9 \\
\hline KATILIYORUM & 65 & 16,6 & 91,6 \\
\hline KESİNLIKKLE KATILIYORUM & 33 & 8,4 & 100,0 \\
\hline TOPLAM & 391 & 100,0 & \\
\hline
\end{tabular}

"Kars’ta çalışma ortamlarında bayan istihdamına yönelik hoşgörü mevcuttur” şeklindeki 23. soruya katılımcıların \%21,5’i (84 kişi) katılmıyorum şeklinde cevap vermiştir.

\begin{tabular}{|l|l|l|l|}
\hline \multicolumn{4}{|c|}{ Tablo 17: Bayan İstihdamına Yönelik Tutum } \\
\hline & N & Geçerli Yüzde & Kümülatif Yüzde \\
\hline KESINLIKLE KATILMIYORUM & 76 & 19,4 & 19,4 \\
\hline KATILMIYORUM & 84 & $\mathbf{2 1 , 5}$ & 40,9 \\
\hline KISMEN KATILIYORUM & 113 & 28,9 & 69,8 \\
\hline KATILIYORUM & 76 & 19,4 & 89,3 \\
\hline KESINLIKKLE KATILIYORUM & 42 & 10,7 & 100,0 \\
\hline TOPLAM & 391 & 100,0 & \\
\hline
\end{tabular}

"Kars'ta kazanılan ücret yasal sınırlar içerisinde belirlenmektedir" şeklindeki 24. soruya katılımcıların \%49,1'i (192 kişi) katılmıyorum şeklinde cevap vermiştir.

\begin{tabular}{|l|l|l|l|}
\hline \multicolumn{4}{|c|}{ Tablo 18: Yasal Ücret Seviyesi } \\
\hline & $\mathrm{N}$ & Geçerli Yüzde & Kümülatif Yüzde \\
\hline KESİNLIKLE KATILMIYORUM & 95 & $\mathbf{2 4 , 3}$ & 24,3 \\
\hline KATILMIYORUM & 97 & $\mathbf{2 4 , 8}$ & 49,1 \\
\hline KISMEN KATILIYORUM & 93 & 23,8 & 72,9 \\
\hline KATILIYORUM & 70 & 17,9 & 90,8 \\
\hline KESİNLIKLLE KATILIYORUM & 36 & 9,2 & 100,0 \\
\hline TOPLAM & 391 & 100,0 & \\
\hline
\end{tabular}

“Fiziksel taciz söz konusudur” katılımcıların 149 kişi en fazla oranı katılıyorum demiştir.

\begin{tabular}{|c|c|c|c|}
\hline \multicolumn{4}{|l|}{ Tablo 19: Fiziksel Taciz } \\
\hline & $\mathrm{N}$ & Geçerli Yüzde & Kümülatif Yüzde \\
\hline KESINLIKLLE KATILMIYORUM & 34 & 8,7 & 8,7 \\
\hline KATILMIYORUM & 34 & 8,7 & 17,4 \\
\hline KISMEN KATILIYORUM & 75 & 19,2 & 36,6 \\
\hline
\end{tabular}




\begin{tabular}{|l|l|l|l|}
\hline KATILIYORUM & 149 & 38,1 & 74,7 \\
\hline KESINLIKLE KATILIYORUM & 99 & 25,3 & 100,0 \\
\hline TOPLAM & 391 & 100,0 & \\
\hline
\end{tabular}

“Kars'taki işyerlerinde psikolojik taciz söz konusudur" şeklindeki 26. soruya katılımcıların \%31,5'i (123 kişi) yani en fazla oranı katılıyorum şeklinde cevap vermiştir.

\begin{tabular}{|c|c|c|c|}
\hline \multicolumn{4}{|c|}{ Tablo 20: Psikolojik Taciz } \\
\hline & $\mathrm{N}$ & Geçerli Yüzde & Kümülatif Yüzde \\
\hline KESINLIKLE KATILMIYORUM & 52 & 13,3 & 13,3 \\
\hline KATILMIYORUM & 55 & 14,1 & 27,4 \\
\hline KISMEN KATILIYORUM & 89 & 22,8 & 50,1 \\
\hline KATILIYORUM & 123 & 31,5 & 81,6 \\
\hline KESINLIKKLE KATILIYORUM & 72 & 18,4 & 100,0 \\
\hline TOPLAM & 391 & 100,0 & \\
\hline
\end{tabular}

"Kars'taki işyerlerinde giyim kuşam eleştiri konusu olabilmektedir" şeklindeki 27. soruya katılımcıların \%19,9’u (78 kişi) katılmıyorum şeklinde cevap vermiştir.

\begin{tabular}{|l|l|l|l|}
\hline \multicolumn{4}{|c|}{ Tablo 21: Giyim Kuşam Eleştirisi } \\
\hline & $\mathrm{N}$ & Geçerli Yüzde & Kümülatif Yüzde \\
\hline KESINLIKLE KATILMIYORUM & 74 & 18,9 & 18,9 \\
\hline KATILMIYORUM & 78 & $\mathbf{1 9 , 9}$ & 38,9 \\
\hline KISMEN KATILIYORUM & 108 & 27,6 & 66,5 \\
\hline KATILIYORUM & 72 & 18,4 & 84,9 \\
\hline KESINLIKLE KATILIYORUM & 59 & 15,1 & 100,0 \\
\hline TOPLAM & 391 & 100,0 & \\
\hline
\end{tabular}

"Kars’taki işyerlerinde işin yapılmasını sağlayan ekipman noksansız olarak vardır" şeklindeki 28. soruya katılımcıların \%25,6’u (100 kişi) katılmıyorum şeklinde cevap vermiştir.

\begin{tabular}{|c|c|c|c|}
\hline \multicolumn{4}{|c|}{ Tablo 22: Ekipman Yeterliliği } \\
\hline & $\mathrm{N}$ & Geçerli Yüzde & Kümülatif Yüzde \\
\hline KESINLIKLE KATILMIYORUM & 71 & 18,2 & 18,2 \\
\hline KATILMIYORUM & 100 & 25,6 & 43,7 \\
\hline KISMEN KATILIYORUM & 148 & 37,9 & 81,6 \\
\hline KATILIYORUM & 41 & 10,5 & 92,1 \\
\hline KESINLIKLE KATILIYORUM & 31 & 7,9 & 100,0 \\
\hline TOPLAM & 391 & 100,0 & \\
\hline
\end{tabular}

"Kars'taki işyerlerinde ortaya çıkan zararlar çalışan ücretlerine yansıtılmaktadır" şeklindeki 29. soruya katılımcıların \%26,1’i (102 kişi) katılıyorum şeklinde cevap vermiştir.

Tablo 23: Zararın Çalışan Ücretine Yansıtılması 


\begin{tabular}{|l|l|l|l|}
\hline & N & Geçerli Yüzde & Kümülatif Yüzde \\
\hline KESINLIKLE KATILMIYORUM & 40 & 10,2 & 10,2 \\
\hline KATILMIYORUM & 67 & 17,1 & 27,4 \\
\hline KISMEN KATILIYORUM & 127 & 32,5 & 59,8 \\
\hline KATILIYORUM & 102 & $\mathbf{2 6 , 1}$ & 85,9 \\
\hline KESINLIKLE KATILIYORUM & 55 & 14,1 & 100,0 \\
\hline TOPLAM & 391 & 100,0 & \\
\hline
\end{tabular}

"Kars'ta işe alım ve işten çıkarma işlemleri yasalara uygun olarak yapılmaktadır" şeklindeki 30. soruya katılımcıların \%28,6'sı (112 kişi) kesinlikle katılmıyorum şeklinde cevap vermiştir.

Tablo 24: İşe Alımda ve İşten Çıkarmada Yasal Uygunluk

\begin{tabular}{|l|l|l|l|}
\hline & $\mathrm{N}$ & Geçerli Yüzde & Kümülatif Yüzde \\
\hline KESINLIKLLE KATILMIYORUM & 112 & $\mathbf{2 8 , 6}$ & 28,6 \\
\hline KATILMIYORUM & 90 & 23,0 & 51,7 \\
\hline KISMEN KATILIYORUM & 123 & 31,5 & 83,1 \\
\hline KATILIYORUM & 37 & 9,5 & 92,6 \\
\hline KESINLIKLE KATILIYORUM & 29 & 7,4 & 100,0 \\
\hline TOPLAM & 391 & 100,0 & \\
\hline
\end{tabular}

“Kars’taki iş yerlerinde çocuk işçi çalıştırılması durumu gözlenmektedir” şeklindeki 31. soruya katılımcıların \%20,2'si (79 kişi) katılıyorum şeklinde cevap vermiştir.

\begin{tabular}{|l|l|l|l|}
\hline \multicolumn{4}{|c|}{ Tablo 25: Çocuk İşçi Çalıştırma Durumu } \\
\hline & $\mathrm{N}$ & Geçerli Yüzde & Kümülatif Yüzde \\
\hline KESINLIKKLE KATILMIYORUM & 54 & 13,8 & 13,8 \\
\hline KATILMIYORUM & 66 & 16,9 & 30,7 \\
\hline KISMEN KATILIYORUM & 120 & 30,7 & 61,4 \\
\hline KATILIYORUM & 79 & $\mathbf{2 0 , 2}$ & 81,6 \\
\hline KESINNLIKLE KATILIYORUM & 72 & 18,4 & 100,0 \\
\hline TOPLAM & 391 & 100,0 & \\
\hline
\end{tabular}

"Kars’taki iş yerlerinde engelli personel istihdamı yapılmaktadır” şeklindeki 32. soruya katılımcıların \%27,4’ü (107 kişi) katılmıyorum şeklinde cevap vermiştir.

Tablo 26: Engelli Personel Çalıştırma Durumu

\begin{tabular}{|l|l|l|l|}
\hline & N & Geçerli Yüzde & Kümülatif Yüzde \\
\hline KESINLIKLE KATILMIYORUM & 92 & 23,5 & 23,5 \\
\hline KATILMIYORUM & 107 & $\mathbf{2 7 , 4}$ & 50,9 \\
\hline KISMEN KATILIYORUM & 131 & 33,5 & 84,4 \\
\hline KATILIYORUM & 35 & 9,0 & 93,4 \\
\hline
\end{tabular}




\begin{tabular}{|l|l|l|l|}
\hline KESINLIKLE KATILIYORUM & 26 & 6,6 & 100,0 \\
\hline TOPLAM & 391 & 100,0 & \\
\hline
\end{tabular}

"Kars’taki iş yerlerinde yasalara uygun olarak engelli hareket alanları sağlanmıştır" şeklindeki 33. soruya katılımcıların \%27,4’ü (107 kişi) katılmıyorum şeklinde cevap vermiştir.

Tablo 27: Engelliler için Uygun Hareket Alanları

\begin{tabular}{|l|l|l|l|}
\hline & N & Geçerli Yüzde & Kümülatif Yüzde \\
\hline KESINLIKLE KATILMIYORUM & 104 & 26,6 & 26,6 \\
\hline KATILMIYORUM & 107 & $\mathbf{2 7 , 4}$ & 54,0 \\
\hline KISMEN KATILIYORUM & 127 & 32,5 & 86,4 \\
\hline KATILIYORUM & 38 & 9,7 & 96,2 \\
\hline KESINNLIKLE KATILIYORUM & 15 & 3,8 & 100,0 \\
\hline TOPLAM & 391 & 100,0 & \\
\hline
\end{tabular}

"Kars’taki iş yerlerinde çalışanların düşünce ve önerilerine değer verilmektedir" şeklindeki 34. soruya katılımcıların \%26,3’ü (103 kişi) katılmıyorum şeklinde cevap vermiştir.

\begin{tabular}{|l|l|l|l|}
\hline \multicolumn{4}{|c|}{ Tablo 28: Çalışanların Düşüncelerine Verilen Değer } \\
\hline & $\mathrm{N}$ & Geçerli Yüzde & Kümülatif Yüzde \\
\hline KESINLIKKLE KATILMIYORUM & 86 & 22,0 & 22,0 \\
\hline KATILMIYORUM & 103 & $\mathbf{2 6 , 3}$ & 48,3 \\
\hline KISMEN KATILIYORUM & 133 & 34,0 & 82,4 \\
\hline KATILIYORUM & 44 & 11,3 & 93,6 \\
\hline KESİNLIKKLE KATILIYORUM & 25 & 6,4 & 100,0 \\
\hline TOPLAM & 391 & 100,0 & \\
\hline
\end{tabular}

“Kars'taki iş yerlerinde çalışanlara çeşitli kariyer fırsatları sunulmaktadır” şeklindeki 35. soruya katılımcıların \%38,1'i (149 kişi) dolayısıyla en fazla oranı katılmıyorum şeklinde cevap vermiştir.

\begin{tabular}{|l|l|l|l|}
\hline \multicolumn{5}{|c|}{ Tablo 29: Çalışanlara Sunulan Kariyer Firsatları } \\
\hline & $\mathrm{N}$ & Geçerli Yüzde & Kümülatif Yüzde \\
\hline KESİNLIKLE KATILMIYORUM & 104 & 26,6 & 26,6 \\
\hline KATILMIYORUM & 149 & $\mathbf{3 8 , 1}$ & 64,7 \\
\hline KISMEN KATILIYORUM & 86 & 22,0 & 86,7 \\
\hline KATILIYORUM & 34 & 8,7 & 95,4 \\
\hline KESINLIKLE KATILIYORUM & 18 & 4,6 & 100,0 \\
\hline TOPLAM & 391 & 100,0 & \\
\hline
\end{tabular}

"Kars'taki iş yerlerinde çalışanlara gerekli iş yeri eğitimi verilmektedir" şeklindeki 36. soruya katılımcıların \%27,6’sı (108 kişi) katılmıyorum şeklinde cevap vermiştir.

\begin{tabular}{|l|l|l|l|}
\hline \multicolumn{3}{|c|}{ Tablo 30: İşyeri Eğitiminin Verilmesi } \\
\hline & $\mathrm{N}$ & Geçerli Yüzde & Kümülatif Yüzde \\
\hline KESİNLIKKLE KATILMIYORUM & 103 & 26,3 & 26,3 \\
\hline KATILMIYORUM & 108 & $\mathbf{2 7 , 6}$ & 54,0 \\
\hline
\end{tabular}




\begin{tabular}{|l|l|l|l|}
\hline KISMEN KATILIYORUM & 115 & 29,4 & 83,4 \\
\hline KATILIYORUM & 44 & 11,3 & 94,6 \\
\hline KESINLIKLE KATILIYORUM & 21 & 5,4 & 100,0 \\
\hline TOPLAM & 391 & 100,0 & \\
\hline
\end{tabular}

"IŞKUR çalışmak isteyenlere istihdam konusunda gerekli yardımı yapmaktadır" şeklindeki 37. Soruya katılımcıları \%19,9’u (78 kişi) katılmıyorum şeklinde cevap vermiştir.

Tablo 31: İŞKUR'un İş Arayana Desteği

\begin{tabular}{|l|l|l|l|}
\hline & N & Geçerli Yüzde & Kümülatif Yüzde \\
\hline KESINLIKLE KATILMIYORUM & 69 & 17,6 & 17,6 \\
\hline KATILMIYORUM & 78 & $\mathbf{1 9 , 9}$ & 37,6 \\
\hline KISMEN KATILIYORUM & 140 & 35,8 & 73,4 \\
\hline KATILIYORUM & 63 & 16,1 & 89,5 \\
\hline KESINLIKLE KATILIYORUM & 41 & 10,5 & 100,0 \\
\hline TOPLAM & 391 & 100,0 & \\
\hline
\end{tabular}

"IŞKUUR iş başı eğitim programları ile istenilen istihdam elemanını yetiştirmektedir" şeklindeki 38. Soruya katılımcıları \%21'i (82 kişi) katılmıyorum şeklinde cevap vermiştir.

\begin{tabular}{|l|l|l|l|}
\hline \multicolumn{5}{|c|}{ Tablo 32: İSKKUR'un Nitelikli Eleman Temini } \\
\hline & $\mathrm{N}$ & Geçerli Yüzde & Kümülatif Yüzde \\
\hline KESINLIKLE KATILMIYORUM & 80 & 20,5 & 20,5 \\
\hline KATILMIYORUM & 82 & $\mathbf{2 1 , 0}$ & 41,4 \\
\hline KISMEN KATILIYORUM & 136 & 34,8 & 76,2 \\
\hline KATILIYORUM & 56 & 14,3 & 90,5 \\
\hline KESINLIKKLE KATILIYORUM & 37 & 9,5 & 100,0 \\
\hline TOPLAM & 391 & 100,0 & \\
\hline
\end{tabular}

\subsection{Kars’taki İstihdam Algısına Yönelik Genel Bir Değerlendirme}

Kars Kafkas üniversitesi öğrencileri tarafından istihdam ve işsizlikle ilgili sorulara verilen cevaplar genel olarak değerlendirildiğinde orta düzeyde $(2,7295)$ bir olumlu algılama söz konusudur. İlerleyen sayfalarda farklılık testleri başlığı altında yapılan analizlerde yukarıdaki 38 sorudan oluşan İstihdama bakış boyutu ile ilgili değerde farklılık aranmaktadır.

\begin{tabular}{|c|c|c|c|}
\hline \multicolumn{4}{|c|}{ Tablo 33: Genel İstihdam Alg1S1 } \\
\hline & $\mathrm{N}$ & Ortalama & Standart Sapma \\
\hline İSTiHDAM & 391 & $\mathbf{2 , 7 2 9 5}$ &, 53226 \\
\hline
\end{tabular}

\subsection{Kars İlinde Sunulan Sosyo-Kültürel Olanakların Yeterliliği}


\% 14,8 (58 kişi)'i sosyo-kültürel olanakların yeterli olduğunu belirtmişken, \% 85,2(333 kişi)'si sosyo-kültürel olanakların yetersiz olduğunu belirtmişlerdir.

\begin{tabular}{|l|l|l|l|}
\hline \multicolumn{3}{|c|}{ Tablo 34: Kars İlindeki Sosyo-Kültürel Olanakların Yeterliliği } \\
\hline & $\mathrm{N}$ & Geçerli Yüzde & Kümülatif Yüzde \\
\hline EVET & 58 & 14,8 & 14,8 \\
\hline HAYIR & 333 & 85,2 & 100,0 \\
\hline TOPLAM & 391 & 100,0 & \\
\hline
\end{tabular}

Araştırmaya katılan Kars Kafkas üniversitesi öğrencilerinin \% 10,0 (39 kişi)'1 Kars İlinde ekonomik olanakların yeterli olduğunu belirtmişken, \% 90,0 (352 kişi)'1 ekonomik olanakların yetersiz olduğunu belirtmişlerdir.

\begin{tabular}{|l|l|l|l|}
\hline \multicolumn{4}{|c|}{ Tablo 35: Kars İlindeki Ekonomik Olanakların Yeterlilĭğ } \\
\hline & $\mathrm{N}$ & Geçerli Yüzde & Kümülatif Yüzde \\
\hline EVET & 39 & 10,0 & 10,0 \\
\hline HAYIR & 352 & 90,0 & 100,0 \\
\hline TOPLAM & 391 & 100,0 & \\
\hline
\end{tabular}

\subsection{Kars'taki Sosyo-Kültürel ve Ekonomik Yapının Bir Bütün Olarak Değerlendirilmesi}

Araştırmaya katılan Kars Kafkas üniversitesi öğrencilerinin Kars İlinde en önemli ve en önemsiz gördüğ̈ ifadeler şunlardır.

$>$ En önemli: Kars ilinde öğrencilerin çalışmasına hoşgörü ile bakılmaktadır $(3,09)$

$>$ En yetersiz: Kars ilinde barınma giderleri için ödenen miktar uygundur $(1,94)$

\begin{tabular}{|l|l|l|l|l|l|l|}
\hline Tablo 36: Kars'ın Sosyo-Kültürel ve Ekonomik Durumu ile İlgili İfadeler \\
\hline & $\mathrm{N}$ & $\begin{array}{c}\text { En } \\
\text { az }\end{array}$ & $\begin{array}{c}\text { En } \\
\text { fazla }\end{array}$ & Ortalama & $\begin{array}{l}\text { Standart } \\
\text { Sapma }\end{array}$ \\
\hline Öğrencilerin çalışmasına hoşgörü ile bakılmaktadır. & 391 & 1 & 5 & $\mathbf{3 , 0 9}$ & 1,200 \\
\hline Barınma giderleri için ödenen miktar uygundur. & 391 & 1 & 5 & $\underline{1,94}$ & 1,154 \\
\hline Yeterli sosyal tesis vardır (sinema, kafe, tiyatro). & 391 & 1 & 5 & 2,15 & 1,203 \\
\hline Yeterli eğitim kuruluşu vardır (Ales, KPSS kursu). & 391 & 1 & 5 & 2,36 & 1,172 \\
\hline Sağlık olanakları yeterlidir (sağlık Ocağı, Hastane). & 391 & 1 & 5 & 2,59 & 1,301 \\
\hline
\end{tabular}

\subsection{Kars’taki Sosyo-Kültürel ve Ekonomik Yapının Ayrı Ayrı Değerlendirilmesi}

"Kars ilinde öğrencilerin çalışmasına hoşgörü ile bakılmaktadır" şeklinde sorulan 41. soruya katılımcıların \%23,3’ü (91 kişi) katılıyorum diyerek cevap vermiştir. 


\begin{tabular}{|l|l|l|l|}
\hline & $\mathrm{N}$ & Geçerli Yüzde & Kümülatif Yüzde \\
\hline KESINLIKLE KATILMIYORUM & 50 & 12,8 & 12,8 \\
\hline KATILMIYORUM & 62 & 15,9 & 28,6 \\
\hline KISMEN KATILIYORUM & 135 & 34,5 & 63,2 \\
\hline KATILIYORUM & 91 & $\mathbf{2 3 , 3}$ & 86,4 \\
\hline KESINLIKLE KATILIYORUM & 53 & 13,6 & 100,0 \\
\hline TOPLAM & 391 & 100,0 & \\
\hline
\end{tabular}

"Kars ilinde barınma giderleri için ödenen miktar uygundur" şeklinde sorulan 42. soruya katılımcıların \%48,1'i (188 kişi) yani en fazla oranı kesinlikle katılmıyorum diyerek cevap vermiştir.

\begin{tabular}{|l|l|l|l|}
\hline \multicolumn{5}{|c|}{ Tablo 38: Barınma Giderlerine Yönelik Tutum } \\
\hline & N & Geçerli Yüzde & Kümülatif Yüzde \\
\hline KESINLIKLE KATILMIYORUM & 188 & $\mathbf{4 8 , 1}$ & 48,1 \\
\hline KATILMIYORUM & 105 & 26,9 & 74,9 \\
\hline KISMEN KATILIYORUM & 53 & 13,6 & 88,5 \\
\hline KATILIYORUM & 25 & 6,4 & 94,9 \\
\hline KESINLIKKLE KATILIYORUM & 20 & 5,1 & 100,0 \\
\hline TOPLAM & 391 & 100,0 & \\
\hline
\end{tabular}

"Kars ilinde yeterli sayıda sosyal tesis vardır (sinema, kafe, tiyatro salonu vb...)" şeklinde sorulan 43. soruya katılımcıların \%39,4'i (154 kişi) yani en fazla oranı kesinlikle katılmıyorum diyerek cevap vermiştir.

Tablo 39: Kars İlindeki Sosyal Tesislerin Yeterliliği

\begin{tabular}{|l|l|l|l|}
\hline & N & Geçerli Yüzde & Kümülatif Yüzde \\
\hline KESINLIKLE KATILMIYORUM & 154 & $\mathbf{3 9 , 4}$ & 39,4 \\
\hline KATILMIYORUM & 108 & 27,6 & 67,0 \\
\hline KATMEN KATILIYORUM & 64 & 16,4 & 83,4 \\
\hline KESİNLIKORUE KATILIYORUM & 46 & 11,8 & 95,1 \\
\hline TOPLAM & 19 & 4,9 & 100,0 \\
\hline
\end{tabular}

"Kars ilinde ihtiyaç duyulan eğitimi verecek yeterli kuruluş vardır (ALES, KPSS, Dil Kursları)" şeklinde sorulan 44. soruya katılımcıların \%29,9'u (117 kişi) yani en fazla oranı kesinlikle katılmıyorum diyerek cevap vermiştir.

Tablo 40: Eğitim Kurslarının Yeterliliğine Bakış

\begin{tabular}{|l|l|l|l|}
\hline & N & Geçerli Yüzde & Kümülatif Yüzde \\
\hline KESINLIKLE KATILMIYORUM & 117 & $\mathbf{2 9 , 9}$ & 29,9 \\
\hline KATILMIYORUM & 101 & 25,8 & 55,8 \\
\hline KISMEN KATILIYORUM & 111 & 28,4 & 84,1 \\
\hline KATILIYORUM & 40 & 10,2 & 94,4 \\
\hline
\end{tabular}




\begin{tabular}{|l|l|l|l|}
\hline KESINLIKLE KATILIYORUM & 22 & 5,6 & 100,0 \\
\hline TOPLAM & 391 & 100,0 & \\
\hline
\end{tabular}

"Kars ilinde sunulan sağlık olanakları yeterli düzeydedir (Sağlık ocağı, hastane)" şeklinde sorulan 45. soruya katılımcıların \%27,6'sı (108 kişi) kesinlikle katılmıyorum diyerek cevap vermiştir.

\begin{tabular}{|l|l|l|l|}
\hline \multicolumn{5}{|c|}{ Tablo 41: Sağlık İmkânlarının Yeterliliğine Bakış } \\
\hline & $\mathrm{N}$ & Geçerli Yüzde & Kümülatif Yüzde \\
\hline KESİNLIKLE KATILMIYORUM & 108 & 27,6 & 27,6 \\
\hline KATILMIYORUM & 78 & 19,9 & 47,6 \\
\hline KISMEN KATILIYORUM & 110 & 28,1 & 75,7 \\
\hline KATILIYORUM & 55 & 14,1 & 89,8 \\
\hline KESINLIKLLE KATILIYORUM & 40 & 10,2 & 100,0 \\
\hline TOPLAM & 391 & 100,0 & \\
\hline
\end{tabular}

\subsection{KAÜ’deki Sosyo-Kültürel ve Ekonomik Yapıya Bakış}

Araştırmaya katılmış olan Kafkas Üniversitesi öğrencilerine Kafkas_Üniversitesi’nde sunulan sosyo-kültürel olanakların yeterliliği sorulmuştur. $\% \quad 21,5 \quad\left(\begin{array}{lll}84 & \text { kişii }\end{array}{ }^{\prime} i\right.$ sosyo-kültürel olanakların yeterli olduğunu belirtmişken, \% 78,5 (306 kişi)'i sosyo-kültürel olanakların yetersiz olduğunu belirtmişlerdir.

\begin{tabular}{|l|l|l|l|}
\hline \multicolumn{2}{|c|}{ Tablo 42: Kafkas Üniversitesindeki Sosyo-Kültürel Olanakların Yeterliliğ } \\
\hline & N & Geçerli Yüzde & Kümülatif Yüzde \\
\hline EVET & 84 & $\mathbf{2 1 , 5}$ & 21,5 \\
\hline HAYIR & 306 & $\mathbf{7 8 , 5}$ & 100,0 \\
\hline TOPLAM & 391 & 100,0 & \\
\hline
\end{tabular}

Araştırmaya katılmış olan Kafkas Üniversitesi öğrencilerine Kafkas_Üniversitesi'nde sunulan ekonomik olanakların yeterliliği sorulmuştur. \% 15,9 (62 kişi)'i ekonomik olanakların yeterli olduğunu belirtmişken, \% 84,1 (329 kişi)'i ekonomik olanakların yetersiz olduğunu belirtmişlerdir.

\begin{tabular}{|l|l|l|l|}
\hline \multicolumn{4}{|c|}{ Tablo 43: Kafkas Üniversitesindeki Ekonomik Olanakların Yeterliliği } \\
\hline & $\mathrm{N}$ & Geçerli Yüzde & Kümülattif Yüzde \\
\hline EVET & 62 & 15,9 & 15,9 \\
\hline HAYIR & 329 & $\mathbf{8 4 , 1}$ & 100,0 \\
\hline TOPLAM & 391 & 100,0 & \\
\hline
\end{tabular}

\subsection{Kafkas Üniversitesi'ndeki Sosyo-Kültürel ve Ekonomik Yapının Bir Bütün Olarak Değerlendirilmesi}

Araştırmaya katılmış olan Kafkas Üniversitesi öğrencilerinin Kafkas Üniversitesi'nde sosyokültürel ve ekonomik yapı ile ilgili en önemli ve en önemsiz gördüğü ifadeler şunlardır.

Önemli: Kafkas Üniversitesi öğrencilerine kaliteli bir üniversite eğitimi sunmaktadır $(2,83)$ 
Yetersiz: Kafkas Üniversitesi yeterli sayıda öğrenciye barınma imkânı sunmaktadır $(2,25)$

Tablo 44: KAÜdeki Sosyo-kültürel ve Ekonomik Durumla İlgili ifadeler

\begin{tabular}{|c|c|c|c|c|c|}
\hline & $\mathrm{N}$ & $\begin{array}{l}\text { En } \\
\text { az }\end{array}$ & $\begin{array}{r}\text { En } \\
\text { fazla }\end{array}$ & $\begin{array}{l}\text { Ortala } \\
\text { ma }\end{array}$ & $\begin{array}{l}\text { Standart } \\
\text { Sapma }\end{array}$ \\
\hline Üniversitede kaliteli bir eğitim sunulmaktadır. & 391 & 1 & 5 & 2,83 & 1,138 \\
\hline İhtiyaç sahibi öğrencilere gerekli yardım yapılmaktadır. & 391 & 1 & 5 & 2,40 & 1,109 \\
\hline Barınma imkânları yeterli düzeydedir. & 391 & 1 & 5 & $\underline{2,25}$ & 1,109 \\
\hline Düzenlenen konferans veya seminerler yeterlidir. & 391 & 1 & 5 & 2,46 & 1,210 \\
\hline Yeterli sayıda tesis vardır (Kafeterya, sinema vb...). & 391 & 1 & 5 & 2,29 & 1,254 \\
\hline
\end{tabular}

3.18. Kafkas Üniversitesindeki Sosyo-Kültürel ve Ekonomik Yapının Ayrı Ayrı Değerlendirilmesi

"Kafkas Üniversitesi öğrencilerine kaliteli bir üniversite eğitimi sunmaktadır” şeklinde sorulan 48. soruya katılımcıların \%19,4’̈̈ (76 kişi) katılıyorum diyerek cevap vermiştir.

\begin{tabular}{|l|l|l|l|}
\hline \multicolumn{4}{|c|}{ Tablo 45: Üniversitede Eğitimin Kalitesine Yönelik Tutum } \\
\hline & $\mathrm{N}$ & Geçerli Yüzde & Kümülatif Yüzde \\
\hline KESINLIKLE KATILMIYORUM & 65 & 16,6 & 16,6 \\
\hline KATILMIYORUM & 68 & 17,4 & 34,0 \\
\hline KISMEN KATILIYORUM & 154 & 39,4 & 73,4 \\
\hline KATILIYORUM & 76 & $\mathbf{1 9 , 4}$ & 92,8 \\
\hline KESINLIKKLE KATILIYORUM & 28 & 7,2 & 100,0 \\
\hline TOPLAM & 391 & 100,0 & \\
\hline
\end{tabular}

"Kafkas Üniversitesi ihtiyaç sahibi öğrencilere gerekli yardımı yapmaktadır" şeklinde sorulan 49. soruya katılımcıların \%30,2'i (118 kişi) yani en fazla oranı katılmıyorum diyerek cevap vermiştir.

\begin{tabular}{|l|l|l|l|}
\hline \multicolumn{4}{|c|}{ Tablo 46: İhtiyaç Sahibi Öğrencilere Yapılan Yardıma Yönelik Tutum } \\
\hline & $\mathrm{N}$ & Geçerli Yüzde & Kümülatif Yüzde \\
\hline KESINLIKLE KATILMIYORUM & 98 & 25,1 & 25,1 \\
\hline KATILMIYORUM & 118 & 30,2 & 55,2 \\
\hline KISMEN KATILIYORUM & 114 & 29,2 & 84,4 \\
\hline KATILIYORUM & 44 & 11,3 & 95,7 \\
\hline KESINNLIKLE KATILIYORUM & 17 & 4,3 & 100,0 \\
\hline TOPLAM & 391 & 100,0 & \\
\hline
\end{tabular}

"Kafkas Üniversitesi yeterli sayıda öğrenciye barınma imkânı sunmaktadır.” şeklinde sorulan 50. soruya katılımcıların \%30,7'i (120 kişi) yani en fazla oranı kesinlikle katılmıyorum diyerek cevap vermiştir.

Tablo 47: Üniversitenin Sunduğu Barınma İmkânına Yönelik Tutum

\begin{tabular}{|l|l|l|l|}
\hline & $\mathrm{N}$ & Geçerli Yüzde & Kümülatif Yüzde \\
\hline KESİNLIKLE KATILMIYORUM & 120 & $\mathbf{3 0 , 7}$ & 30,7 \\
\hline KATILMIYORUM & 119 & 30,4 & 61,1 \\
\hline
\end{tabular}


İstihdam ve İşsizlik Sorununun Sosyo-Ekonomik Bağlamında Kars İlinde Çalışan Üniversite Öğrencileri Üzerine Bir Analiz

\begin{tabular}{|l|l|l|l|}
\hline KISMEN KATILIYORUM & 103 & 26,3 & 87,5 \\
\hline KATILIYORUM & 32 & 8,2 & 95,7 \\
\hline KESINLIKLE KATILIYORUM & 17 & 4,3 & 100,0 \\
\hline TOPLAM & 391 & 100,0 & \\
\hline
\end{tabular}

“Kafkas Üniversitesi'nce düzenlenen konferans, konser ve seminerler yeterli düzeydedir" şeklinde sorulan 51. soruya katılımcıların \%28,1'i (110 kişi) yani en fazla oranı kesinlikle katılmıyorum diyerek cevap vermiştir. "Kafkas Üniversitesi kampüsünde yeterli sayıda sosyal tesis vardır (Kafeterya, sinema, spor alan1)" şeklinde sorulan 52. soruya katılımcıların \%36,8'i (114 kişi) yani en fazla oranı kesinlikle katılmıyorum diyerek cevap vermiştir.

\begin{tabular}{|l|l|l|l|}
\hline \multicolumn{5}{|c|}{ Tablo 48: Kampüs İçerisindeki Tesis Sayısına Yönelik Tutum } \\
\hline & N & Geçerli Yüzde & Kümülatif Yüzde \\
\hline KESINLIKLE KATILMIYORUM & 144 & $\mathbf{3 6 , 8}$ & 36,8 \\
\hline KATILMIYORUM & 83 & 21,2 & 58,1 \\
\hline KISMEN KATILIYORUM & 96 & 24,6 & 82,6 \\
\hline KATILIYORUM & 41 & 10,5 & 93,1 \\
\hline KESINLIKKLE KATILIYORUM & 27 & 6,9 & 100,0 \\
\hline TOPLAM & 391 & 100,0 & \\
\hline
\end{tabular}

\subsection{Farklılık Testleri}

Cinsiyete göre istihdama bakış açısı veya istihdam algısının fark edip etmediği analiz edilmiştir. Buna göre yapılan t testi sonucunda bay ve bayanlar arasında istihdama bakış farklılık göstermemiştir ( $\mathrm{p}>0,05)$. Buna göre $\mathrm{H} 1$ hipotezi reddedilmiştir. İstatistikî olarak anlamlı olmasa da erkekler bayanlara göre daha olumlu istihdam algılamışlardır.

\begin{tabular}{|c|c|c|c|c|c|c|c|}
\hline \multicolumn{8}{|c|}{ Tablo 49: Cinsiyet Grup Ortalamaları } \\
\hline & Cinsiyet & $\mathrm{N}$ & Ortalama & Standart Sapma & \multicolumn{3}{|c|}{ Std. Hata Ortalamas 1} \\
\hline \multirow[t]{2}{*}{ İSTIHDAM } & BAY & 207 & 2,7654 &, 56506 & \multicolumn{3}{|l|}{, 03927} \\
\hline & BAYAN & 184 & 2,6892 & ,49117 & \multicolumn{3}{|l|}{, 03621} \\
\hline \multicolumn{8}{|c|}{ Tablo 50: Cinsiyete Göre t Testi } \\
\hline & \multicolumn{2}{|c|}{\begin{tabular}{l|l} 
Varyansların \\
eşitliği için \\
Levene Testi
\end{tabular}} & \multicolumn{5}{|c|}{ Ortalama eşitliği için t-testi } \\
\hline & \multirow[b]{2}{*}{$\mathrm{F}$} & \multirow[b]{2}{*}{ Sig. } & \multirow[b]{2}{*}{ Df } & \multirow{2}{*}{\begin{tabular}{|l|l|} 
Sig. (2- & Ortalama \\
tailed) & Fark
\end{tabular}} & \multirow{2}{*}{\begin{tabular}{|l} 
Standart \\
Hata Fark1
\end{tabular}} & $\begin{array}{l}\text { Farkın } \\
\text { Güven } \\
\text { Aralığ } 1\end{array}$ & $\% 95$ \\
\hline & & & & & & Alt & Üst \\
\hline
\end{tabular}




\begin{tabular}{|l|l|l|l|l|l|l|l|l|l|l|}
\hline ISTIHDAM & $\begin{array}{l}\text { Eşit } \\
\text { Varyans } \\
\text { Kabulü }\end{array}$ & 2,664 &, 103 & 1,413 & 389 & $\mathbf{1 5 8}$ &, 07611 &, 05386 &,- 02978 &, 18200 \\
\hline & $\begin{array}{l}\text { Eşit } \\
\text { Varyans } \\
\text { Reddi }\end{array}$ & & & 1,425 & 388,812 &, 155 &, 07611 &, 05342 &,- 02892 &, 18114 \\
\hline
\end{tabular}

Öğretim düzeyine göre istihdama bakış açısı veya istihdam algısının fark edip etmediği analiz edilmiştir. Buna göre yapılan t testi sonucunda normal ve ikinci öğretim öğrencileri arasında istihdama bakış farklılık göstermemiştir $(\mathrm{p}>0,05)$. Buna göre $\mathrm{H} 2$ hipotezi reddedilmiştir. İstatistikî olarak anlamlı olmasa da ikinci öğretim öğrencileri normallere göre daha olumlu istihdam algılamışlardır.

Tablo 51: Öğretim Durumu Grup Ortalamaları

\begin{tabular}{|l|l|l|l|l|c|}
\hline & Öğretim Durumu & $\mathrm{N}$ & Mean & Std. Deviation & Std. Error Mean \\
\hline \multirow{2}{*}{ İSTİHDAM } & NORMAL ÖĞRETIM & 228 & $\mathbf{2 , 6 9 6 1}$ &, 50254 &, 03328 \\
\cline { 2 - 6 } & İKİNCİ ÖĞRETİM & 163 & $\mathbf{2 , 7 7 6 3}$ &, 56954 &, 04461 \\
\hline
\end{tabular}

\begin{tabular}{|c|c|c|c|c|c|c|c|c|c|c|}
\hline \multicolumn{11}{|c|}{ Tablo 52: Öğretim Durumuna Göre t Testi } \\
\hline & & \multicolumn{2}{|c|}{$\begin{array}{l}\text { Varyansların } \\
\text { eşitliği için } \\
\text { Levene Testi }\end{array}$} & \multicolumn{7}{|c|}{ Ortalama eşitliği için t-testi } \\
\hline & & \multirow[b]{2}{*}{$\mathrm{F}$} & \multirow[b]{2}{*}{ Sig. } & \multirow[b]{2}{*}{$\mathrm{t}$} & \multirow[b]{2}{*}{$\mathrm{df}$} & \multirow{2}{*}{\begin{tabular}{|l} 
Sig. \\
$(2-$ \\
tailed)
\end{tabular}} & \multirow{2}{*}{$\begin{array}{l}\text { Ortalama } \\
\text { Fark }\end{array}$} & \multirow{2}{*}{$\begin{array}{l}\text { Standart } \\
\text { Hata Fark1 }\end{array}$} & \multicolumn{2}{|c|}{$\begin{array}{l}\text { Farkın } \\
\text { Güven } \\
\text { Aralığı }\end{array}$} \\
\hline & & & & & & & & & Alt & Üst \\
\hline \multirow[t]{2}{*}{ İSTIHDAM } & \begin{tabular}{|l} 
Eşit \\
Varyans \\
Kabulü
\end{tabular} & 2,215 & ,137 & 1,471 & 389 &, 142 &,- 08018 &, 05451 & 18736 &, 02700 \\
\hline & $\begin{array}{l}\text { Eşit } \\
\text { Varyans } \\
\text { Reddi }\end{array}$ & & & 1,441 & 321,457 &, 151 &,- 08018 &, 05566 &, 18967 &, 02932 \\
\hline
\end{tabular}

Çalışma yerine göre istihdama bakış açısı veya istihdam algısının fark eddip etmediği analiz edilmiştir. Buna göre yapılan ANOVA testi sonucunda Özel, Kamu ve Üniversitede çalışan öğrenciler arasında istihdama bakış anlamlı farklılık göstermiştir $(p<0,05)$. Buna göre H3 hipotezi kabul edilmiştir. Farklılığın hangi gruplar arasında olduğunu belirlemek için post-hoc testleri yapılmıştır. Eşit homojenlik durumu neticesindeki TUKEY testi sonucuna göre kamuda çalışan öğrenciler özelde ve üniversite çalışanlara göre istihdama daha olumlu bakmış veya daha olumlu algılamışlardır.

Tablo 53: Çalışma Yeri İle İlgili Tanımlayıcı İstatistikler

\begin{tabular}{|c|c|c|c|c|c|c|c|c|}
\hline \multicolumn{9}{|l|}{ İSTIHHDAM } \\
\hline & \multirow[b]{2}{*}{$\mathrm{N}$} & \multirow{2}{*}{$\begin{array}{l}\text { Ortala } \\
\text { ma }\end{array}$} & \multirow{2}{*}{$\begin{array}{l}\text { Standart } \\
\text { Sapma }\end{array}$} & \multirow{2}{*}{$\begin{array}{l}\text { Standa } \\
\text { rt } \\
\text { Hata }\end{array}$} & \multicolumn{2}{|c|}{$\begin{array}{c}\begin{array}{c}\% 5 \\
\text { Ortalamas1 }\end{array} \\
\text { Güven Aralığ } 1\end{array}$} & \multirow[b]{2}{*}{ En $\mathrm{Az}$} & \multirow[b]{2}{*}{ En Fazla } \\
\hline & & & & & Alt Sinır & Üst Sinır & & \\
\hline ÖZEL & 287 & 2,7091 & ,52757 & ,03114 & 2,6478 & 2,7704 & 1,04 & 4,57 \\
\hline KAMU & 54 & 2,9067 & ,55517 &, 07555 & 2,7552 & 3,0583 & 1,36 & 4,43 \\
\hline ÜNIVERSITE & 50 & 2,6557 &, 50429 &, 07132 & 2,5124 & 2,7990 & 1,75 & 3,79 \\
\hline
\end{tabular}


Tablo 53: Çalışma Yeri İle İlgili Tanımlayıcı İstatistikler

\begin{tabular}{|c|c|c|c|c|c|c|c|c|}
\hline \multicolumn{9}{|l|}{ İSTIHDAM } \\
\hline & \multirow[b]{2}{*}{$\mathrm{N}$} & \multirow{2}{*}{$\begin{array}{l}\text { Ortala } \\
\text { ma }\end{array}$} & \multirow{2}{*}{$\begin{array}{l}\text { Standart } \\
\text { Sapma }\end{array}$} & \multirow{2}{*}{$\begin{array}{l}\text { Standa } \\
\mathrm{rt} \\
\text { Hata }\end{array}$} & \multicolumn{2}{|c|}{$\begin{array}{l}\% 95 \text { Güven Aralığ } \\
\text { Ortalaması }\end{array}$} & \multirow[b]{2}{*}{ En Az } & \multirow[b]{2}{*}{ En Fazla } \\
\hline & & & & & Alt Sinır & Üst Sinır & & \\
\hline ÖZEL & 287 & 2,7091 & \begin{tabular}{|l|}
, 52757 \\
\end{tabular} &, 03114 & 2,6478 & 2,7704 & 1,04 & 4,57 \\
\hline KAMU & 54 & 2,9067 & ,55517 & 07555 & 2,7552 & 3,0583 & 1,36 & 4,43 \\
\hline ÜNIVERSITE & 50 & 2,6557 & ,50429 &, 07132 & 2,5124 & 2,7990 & 1,75 & 3,79 \\
\hline TOPLAM & 391 & 2,7295 & ,53226 & 年, & 2,6766 & 2,7825 & 1,04 & 4,57 \\
\hline
\end{tabular}

Tablo 54: Homojenlik Testi

\begin{tabular}{|l|l|l|l|}
\hline İSTiHDAM & & & \\
\hline Levene İstatistiği & $\mathrm{df1}$ & $\mathrm{df2}$ & Sig. \\
\hline, 052 & 2 & 388 &, 949 \\
\hline
\end{tabular}

\begin{tabular}{|l|l|l|l|l|l|}
\hline \multicolumn{2}{|c|}{ Tablo 55: ANOVA Testi } & & & \\
\hline İSTiHDAM & & & & & Sig. \\
\hline & Kareler Toplamı & Df & Kartalams 1 & F & Sig. \\
\hline Gruplar Arasında & 2,089 & 2 & 1,044 & 3,738 & $\mathbf{0 2 5}$ \\
\hline Gruplar İçinde & 108,398 & 388 &, 279 & & \\
\hline Toplam & 110,487 & 390 & & & \\
\hline
\end{tabular}

\begin{tabular}{|c|c|c|c|c|c|c|}
\hline \multicolumn{7}{|c|}{ Tablo 56: TUKEY Testi } \\
\hline \multicolumn{7}{|c|}{\begin{tabular}{|l|l|l} 
İSTIHDAM & &
\end{tabular}} \\
\hline \multirow[b]{2}{*}{ (I) $\operatorname{dem} 10$} & \multirow[b]{2}{*}{ (J) $\operatorname{dem} 10$} & \multirow{2}{*}{$\begin{array}{l}\text { Ortalama } \\
\text { Fark } \\
\text { (I-J) }\end{array}$} & \multirow[b]{2}{*}{$\begin{array}{l}\text { Standart } \\
\text { Hata }\end{array}$} & \multirow[b]{2}{*}{ Sig. } & \multicolumn{2}{|c|}{ \% 95 Güven Aralığ1 } \\
\hline & & & & & $\begin{array}{c}\text { Gruplar } \\
\text { Arasinda }\end{array}$ & Gruplar İçinde \\
\hline \multirow[t]{2}{*}{ ÖZEL } & KAMU &,$- 19769^{*}$ &, 07840 &, 032 &,- 3821 &,- 0132 \\
\hline & ÜNIVERSITE & 05334 & 08100 & ,788 &,- 1372 & ,2439 \\
\hline \multirow[t]{2}{*}{ KAMU } & ÖZEL & ,19769* & ,07840 & ,032 &, 0132 & ,3821 \\
\hline & ÜNIVERSITE & ,25103* & ,10374 &, 042 &, 0070 & ,4951 \\
\hline \multirow[t]{2}{*}{ ÜNIVERSITE } & ÖZEL &,- 05334 & , 08100 & ,788 &,- 2439 & ,1372 \\
\hline & KAMU &,$- 25103^{*}$ & 10374 & ,042 &,- 4951 &,- 0070 \\
\hline \multicolumn{4}{|c|}{ * 0.05 Düzeyinde anlamı fark bulundu } & & & \\
\hline
\end{tabular}

Yaş aralığına göre istihdama bakış açısı veya istihdam algısının fark edip etmediği de tanımlayıcı istatistikler (ortalamalar) yoluyla analiz edilmiştir. Buna göre genellikle 21 yaşından itibaren yaş arttıkça istihdama bakış daha olumlu olmaktadır. Ayrıca 20 yaşından küçük çalışanların istihdama bakışı 20-30 yaş arasına göre daha yüksektir. 
Tablo 57: Yaş İle İlgili İstatistikler

\begin{tabular}{|l|l|l|l|}
\cline { 1 - 2 } İSTIHDAM & & & \\
\cline { 1 - 3 } & $\mathrm{N}$ & Ortalama & \multirow{2}{*}{ Standart Sapma } \\
\hline $15-20$ & 106 & 2,7520 &, 52178 \\
\hline $21-25$ & 212 & 2,6856 &, 53934 \\
\hline $26-30$ & 49 & 2,7070 &, 43104 \\
\hline $31-35$ & 12 & $\mathbf{2 , 9 6 4 3}$ &, 63633 \\
\hline 36 VE ÜSTÜ & 12 & $\mathbf{3 , 1 6 3 7}$ &, 58317 \\
\hline TOPLAM & 391 & 2,7295 & \\
\hline
\end{tabular}

Kars'ta bulunma süresine göre istihdama bakış açısı veya istihdam algısının fark edip etmediği de tanımlayıcı istatistikler (ortalamalar) yoluyla analiz edilmiştir. Buna göre genellikle üçüncü yıldan sonra süre arttıkça istihdama bakış daha olumlu olmaktadır. Ayrıca öğrencilerin ilk iki yıl istihdama bakışı açısı üçüncü ve dördüncü yıla göre daha yüksektir.

\begin{tabular}{|c|c|c|c|}
\hline \multicolumn{4}{|c|}{ Tablo 58: Kars’ta Bulunma Süresi İle İlgili İstatistikler } \\
\hline İSTİHDAM & & & \\
\hline & $\mathrm{N}$ & Ortalama & Standart Sapma \\
\hline 1 YIL VE DAHA AZ & 57 & 2,7450 & ,46135 \\
\hline 2 YIL & 66 & 2,7132 & 39007 \\
\hline $3 \mathrm{YIL}$ & 60 & 2,5155 & ,45554 \\
\hline $4 \mathrm{YIL}$ & 83 & 2,5839 &, 52907 \\
\hline 5 YIL VE DAHA FAZLA & 125 & 2,9306 & ,59493 \\
\hline TOPLAM & 391 & 2,7295 & ,53226 \\
\hline
\end{tabular}

Öğrencilerin okudukları Fakülteye göre istihdama bakış açısı veya istihdam algısının fark edip etmediği de tanımlayıcı istatistikler (Ortalamalar) yoluyla analiz edilmiştir. Buna göre Formasyon öğrencilerinin ve Kazım Karabekir MYO öğrencilerinin olumlu istihdam algıları diğerlerine göre daha yüksek iken en düşük istihdam algısı Fen Edebiyat Fakültesi öğrencilerindedir.

Tablo 59: Fakülte İle İlgili İstatistikler

\begin{tabular}{|c|c|c|c|}
\hline İSTİHDAM & & & \\
\hline & $\mathrm{N}$ & Ortalama & Standart Sapma \\
\hline İ̈BF & 149 & 2,7191 & $, 5,7403$ \\
\hline FEN EDEBIYYAT & 36 & 2,6131 &, 53428 \\
\hline KAZIM KARABEKİR MYO & 39 & 2,9322 &, 55618 \\
\hline EĞíTì & 60 & 2,6399 & ,47818 \\
\hline ATATÜRK SHMYO & 26 & 2,6731 & ,47667 \\
\hline VETERINEER & 26 & 2,6470 & ,3i8377 \\
\hline KARS MYO & 24 & 2,7515 & ,42133 \\
\hline FORMASYON ÖĞRENCILERİ & 31 & 2,9332 &, 54443 \\
\hline TOPLAM & 391 & 2,7295 &, 53226 \\
\hline
\end{tabular}


Aile aylık gelirine göre istihdama bakış açısı veya istihdam algısının fark edip etmediği de tanımlayıcı istatistikler (Ortalamalar) yoluyla analiz edilmiştir. Buna göre 3000 TL'den fazla aile geliri olanların olumlu istihdam algısı diğerlerine göre daha düşük düzeydedir.

\begin{tabular}{|c|c|c|c|}
\hline \multicolumn{4}{|c|}{ Tablo 60: Aile Aylık Geliri İle İlgili İstatistikler } \\
\hline İSTİHDAM & & & \\
\hline & $\mathrm{N}$ & Ortalama & Standlart Sapma \\
\hline 1000 TL DEN AZ & 103 & 2,7809 & ,5073i5 \\
\hline $1001-1500 \mathrm{TL}$ & 118 & 2,6737 & ,52564 \\
\hline $1501-2000$ & 70 & 2,7526 & , 4998:6 \\
\hline $2001-2500$ & 63 & 2,7443 & ,50663 \\
\hline $2501-3000$ & 19 & 2,8120 & ,76421 \\
\hline 3001 DEN FAZLA & 18 & 2,5734 & 64081 \\
\hline TOPLAM & 391 & 2,7295 &, 53226 \\
\hline
\end{tabular}

Aylık toplam harcamaya göre istihdama bakış açısı veya istihdam algısının fark edip etmediği de tanımlayıcı istatistikler (Ortalamalar) yoluyla analiz edilmiştir. Buna göre 1500 TL'den fazla harcaması olan öğrencilerin olumlu istihdam algısı diğerlerine göre daha fazladır.

\begin{tabular}{|l|l|l|l|}
\hline \multicolumn{4}{|c|}{ Tablo 61: Aylik Harcama İle İlgili İstatistikler } \\
\hline İSTIHDAM & \multicolumn{3}{l|}{} \\
\hline & $\mathrm{N}$ & Ortalama & Standart Sapma \\
\hline & 212 & 2,7340 &, 49802 \\
\hline 500 TL DEN AZ & 132 & 2,7284 &, 49436 \\
\hline 501-1000 TL & 21 & 2,4150 &, 78054 \\
\hline $1001-1500$ & 26 & $\mathbf{2 , 9 5 3 3}$ &, 65026 \\
\hline TOP00 TL DEN FAZLA & 391 & 2,7295 &, 53226 \\
\hline
\end{tabular}

Aylık gelire göre istihdama bakış açısı veya istihdam algısının fark edip etmediği de tanımlayıcı istatistikler (Ortalamalar) yoluyla analiz edilmiştir. Buna göre 1500 TL'den fazla geliri olan öğrencilerin istihdam algısı diğerlerine göre daha fazladır.

\begin{tabular}{|c|c|c|c|}
\hline \multicolumn{4}{|c|}{ Tablo 62: Ayl1k Gelir İle İlgili İstatistikler } \\
\hline İSTIHDAM & \multirow[b]{2}{*}{$\mathrm{N}$} & \multirow[b]{2}{*}{ Ortalama } & \multirow[b]{2}{*}{ Standart Sapma } \\
\hline & & & \\
\hline 500 TL DEN AZ & 221 & 2,6744 & ,45550 \\
\hline $501-1000 \mathrm{TL}$ & 116 & 2,7709 & 60759 \\
\hline $1001-1500$ & 29 & 2,7660 & ,57004 \\
\hline 1500 TL DEN FAZLA & 25 & 2,9829 & 66999 \\
\hline TOPLAM & 391 & 2,7295 & ,53226 \\
\hline
\end{tabular}




\section{SONUÇ ve ÖNERILER}

Çalışma dâhilinde yaklaşık 15.000 öğrencisi bulunan Kafkas Üniversitesi öğrencilerine çalıştıkları işyerleri ile ilgili bir anket uygulanmıştır. Ankete cevap verenlerin \%52,9'u bayan, $\% 47,1$ 'i ise erkektir.

Analiz sonucuna göre ankete katılan öğrencilerin işyerlerinde fiziksel ve psikolojik taciz, işin yapılması esnasında ortaya çıkan zararların çalışan maaşına yansıtılması gibi bir takım sorunlarının olduğu görülmektedir. Öğrencilerin çalışılan işlerde kariyer firsatı bulamadıkları, fazla mesai ücreti alamadıkları ve işyerlerinde engelliler için gerekli hareket alanlarının olmadığı yönünde yetersizlik bildirimleri bulunmaktadır.

Verilen cevaplar neticesinde katılanların \%32,5'i, işyerlerinin gerekli iş̧ güvenliğine ve iş sağlığına uygun olmadığını bildirirken; \%31,7'si işyerlerinin hijyen bakımından uygun olmadığını düşünmektedir. Yine katılımcıların \%28,1'i işveren tarafından yemek veya iş yeri servisi gibi hakların sağlanmadığını belirtmektedir. Böyle bir sonuçla karşı karşıya kalmak bize çalışanın hak ettiği değeri göremediğini, yasal olarak kendine sağlanmış bir takım hakları kullanamadığını düşündürmektedir.

Kars'taki işyerinde genel ahlaka ve genel adaba uygun işlerin yapıldığı ise katılımcıların $\% 26,6$ 'sının olumlu yanıt vermesiyle anlaşılmaktadır. Bu durum genel itibariyle olumlu bir algının oluştuğu yönünde değerlendirilebilir.

Katılımcıların \%28,6'sı fazla mesai ödemesi alamadığını, \%24,8'i sosyall güvenlik priminin yatırılmadığını, \%24,8'i işten çıkış saatlerinin uygun olmadığını yine \%24,8'i yasal ücret seviyesinde gelir elde edemediğini söylemektedir. Bu durum neticessinde temel işyeri haklarının elde edilmesi konusunda aktif rol alması gereken kontrol mekanizmalarının işlevsel olarak görev yapamadığını söylemek mümkündür.

Bayan istihdamına yönelik hoşgörü algısı üzerine tutumları incelenen katılımcıların bir kısmı yani \%21,5'i bu konuda hoşgörünün bulunmadığını belirtirken; \%28,9'u bayan istihdamındaki hoşgörüye yönelik kısmen katılım göstermiştir. Gelişmiş ülke ekonomilerinde kadınların da erkeklerle eşit şartlarda, eşit haklarda rahatça çalışabilme ortamı bulması oldukça kolay iken gelişmekte olan veya gelişim trendi oldukça yavaş olan ülkelerde kadına atfedilen değer her alanda olduğu gibi istihdam konusunda da azdır. Uygulanan anketin 23. Sorusuna verilen cevapların analizi bu durumu kanıtlamaktadır.

Dikkat çekici önemli bir husus ise 184 bayan çalışanın katıldığı araştırmamızda \%38,'1 oran ile 149 katılımcının bayanlara yönelik fiziksel bir tacizin var olduğunu gösteren bir sonuca ulaşmamızdır. Bununla birlikte \%31,5 oranla çalışan üzerinde psikolojik bir baskının var olduğu yönünde bir değerlendirmede vardır. Çalışma koşullarında gerek fiziksel gerek psikolojik bir baskının bulunması elbette ki önemli ve oluşması istenmeyen bir tutumdur. Bu değerlendirme ile birlikte bayanların rahatça çalışacağı, olgunlaşmış bir işgücü piyasasının varlığından söz etmek mümkün değildir. Bu bakımdan önemli olan husus çok sayıda insana istihdam oluşturulması değildir. Uygun sayıda çalışanın en uygun koşullarda istihdam edilmesidir. İstihdam edenlere gerekli eğitimlerin verilmesi huzurlu bir çalışma ortamı oluşturulması için önemli bir gerekliliktir. 
Çalışan öğrencilerde, \%19,9 oran ile giyim kuşamın eleştiri konusu olduğu, \%25,6 oran ile işyerlerinin ekipman bakımından yetersiz olduğu, $\% 26,1$ oran ile işyerlerinde oluşan zararın çalışan ücretlerine yansıtıldığı şeklinde istihdam algısı oluşmuştur. İşyerlerinde çocuk işçi çalıştırıldığına yönelik \%20,2, çalışanlara kariyer firsatlarının sunulması hususunda ise \%38,1 oran ile yetersizlik algısı bulunmaktadır. Katılımcıların \%19,9'u İŞKUR'un gerekli desteği göstermediğini savunurken, \%17,6'sı ise İŞKUR'un kesinlikle iş arayan öğrencilere yönelik bir desteğinin olmadığ1 yönünde görüş bildirmiştir. Temel görevi işgücü arzı ile işgücü talebini karş1laştırmak olan İŞKUR birçok mesleki eğitim kursu ve teşvik edici uygulamalar yapmakta ama bu faaliyetler, öğrenciler tarafından yetersiz görülmektedir. Özel istihdam bürolarının sadece büyük şehirlerde değil geri kalmış şehirlerde de faaliyet göstermesinin ne denli önemli olduğunu savunmak da mümkündür.

Araştırmamıza konu olan diğer bir husus ise çalışan öğrencilerin yaşadıkları şehirden ve okudukları üniversiteden ne kadar memnun olduğudur. Veriler göstermektedir ki katılımcıların \%85,2'si (333 kişi) Kars ilindeki sosyo-kültürel olanakları yeterli görmemektedir. Aynı durum iktisadi olanaklar içinde geçerlidir. Katılımcıların \%90'1 (352 kişi) Kars ilindeki ekonomik olanaklardan hoşnut değildir. Böyle bir algının oluşmasında yüksek ev kiraları, yurt ücretlerindeki pahalılık, kısa mesafelerde yüksek dolmuş ücretleri, ağır geçen kış şartları sebebiyle 1sınma giderlerinin fazlalığı büyük pay sahibidir. Yine yüksek nakliye gideri ödenmesiyle temel tüketim mallarının piyasa fiyatı da yüksektir. Bu sebeple katılımcıların \%48,1'i (188 kişi) Kars ilindeki barınma masraflarının uygunluğuna yönelik olumsuz bir tutum oluşturmuştur. Yine gerekli sayıda sosyal tesisin bulunmadığı, okul dış1 eğitim veren kurum sayısının az olduğu ve sağlık imkânlarının yetersiz olduğu yönünde algı mevcuttur.

Kafkas Üniversitesi'ne yönelik olarak \%78,5 (306 kişi) katılımcının sosyo-kültürel olanakları yeterli görmediği, \%84,1 (329 kişi) katılımcının ise ekonomik olanakları yeterli görmediği sonucu ortaya çıkmaktadır. Üniversitenin en önemli yetersizliği olarak barınma imkânlarının azlığı görülürken, Üniversitede sunulan eğitimin kaliteli olduğu yönündeki alg1 ise memnuniyet vericidir. Bununla birlikte üniversitenin ihtiyaç sahibi öğrencilere maddi yardımda bulunma hususunda, düzenlenen konser, konferans, seminerler ve kampüs içerisinde yer alan tesis sayısının yetersiz olduğu yönünde olumsuz bir alg1 mevcuttur. Fakat bu durumu sadece Kafkas Üniversitesi'ne has bir durum olarak görmekte yersizdir. Türkiye şartlarında birçok üniversitede aynı sıkıntıların yaşandığ üniversitede imkânların daha sınırlı olduğu bilinmesi gereken bir gerçektir. Burada temel amaç karalamak yerine kalkındırmak olmalıdır.

Araştırmamız bir başka boyutu ise istihdam algısının cinsiyete, öğrenim türüne, çalışılan yere göre değişip değişmediğidir. Yapılan analizde bay ve bayanlar arasında istihdama yönelik bakış açısında belirgin farklılık görülmemiştir. Bu yüzden statiksel anlamda belirgin bir farklılığın olduğunu söylemek mümkün değildir fakat erkek algısının bayanlara göre daha olumlu olduğunu belirtmekte fayda vardır. Cinsiyet bazında erkeklerin iş ayırt etmede daha az seçici olması, zor çalışma koşullarına tahammül edebilme kapasitesinin fiziksel olarak fazla olması gibi sebepler böyle bir algının oluşmasında etkili olabilir.

Algıda belirgin farklılığın olmayışı durumu öğrenim türü bakımından da aynı sonucu doğurmuştur. Normal öğretim ve ikinci öğretim öğrencilerine yönelik olarak yapılan analizde belirgin farklılık gözlenmemiştir. İkinci öğretim öğrencilerinin normal öğretim öğrencilerine göre daha olumlu algı oluşturdukları söylenebilir fakat bunun istatistiki bir değeri yoktur. 
İkinci öğretim öğrencilerinde böyle bir algının oluşması eğitim saatleri ile: çalışma saatlerinin aynı saat dilimlerine denk gelmeyişi sebebiyle olabileceği gibi gündüz boş geçen zamanı çalışarak değerlendirme isteğinden de kaynaklandığı düşünülmektedir.

Çalışmamızda çalışma yeri bakımından istihdam algısında belirgin farklılığın olduğunu söyleyebiliriz. Çünkü kamuda çalışan öğrencilerin istihdamı, özel sektörde ve üniversitede (yarı zamanlı) çalışan öğrencilere göre daha olumlu algıladıkları sonucuna ulaşılmıştır. Kamuda çalışan öğrencilerin istihdam koşularından memnun olmasını, mesai saatlerine riayet edilmesine, ücretin zamanında ve tam ödenmesine, sosyal hakların sağlanmış olmasına, nitelikli çalışanların bir arada olmasına, kanunla belirlenmiş hükümlülüklerin yerine getirilmesine bağlamak mümkündür.

İstihdam algısında değerlendirmeye aldığımız diğer hususlar ise şöyledir. Yaşa bağlı olarak istihdam algısında bir değişiklik gözlenmektedir. Çalışan öğrenciler 21 yaşından sonra istihdama daha olumlu bakmaktadır. İlerleyen yaş daha iyi çalışma koşulları elde edebilmede belirli bir tecrübe sağlamakta veya angarya işlerin yapılması için çocuk işçi tercihinin dışında kalmaktadır. Bir diğer önemli değişken ise Kars'ta bulunma süresinin istihdam algısı üzerinde nasıl bir etki oluşturduğudur. Buna göre Kars'ta bulunan öğrenciler ilk iki yıllarında istihdama karşı olumlu bir bakış açısı gösterdiği, üçüncü ve dördüncü yılda bu algının olumsuz bir algıya dönüştügünü söylemek mümkündür. Burada dikkat edilmesi gereken husus süreklilik kavramıdır. Uzun yıllar boyunca bir yerde ikamet eden bireyler o yerin şartlarını daha iyi bilmekte ve ona göre bir tutum geliştirmektedir. Çalışmamızda elde edilen sonuçlardan biri de Kars'ta ikamet eden öğrencilerin üçüncü yıl itibariyle istihdam olanaklarına bakış açısının artış yönlü bir seyir halinde ve olumlu olmasıdır. Eğitim görülen fakülte itibariyle Kazım Karabekir MYO öğrencileri ile Formasyon grubu öğrencilerin istihdam hakkında olumlu alg1, Fen-Edebiyat Fakültesi öğrencilerinin ise olumsuz algı gözlenmiştir. Kazım Karabekir Meslek Yüksek Okulu öğrencileri ile Formasyon grubu öğrencilerinin çalışma alanı olarak daha çok kamuyu tercih etmesi bu farklılığın oluşmasında belirleyici bir etken olabilir. Fen-Edebiyat Fakültesinde gözlenen düşük istihdam algısının nedenini ikinci öğretimde okuyan öğrenci sayısının az olması ile bağdaştırmak mümkündür. Aylık aile geliri bakımından istihdam algısı incelendiğinde aile geliri yüksek olan öğrencilerin istihdama yönelik memnuiyetinin daha az olduğu sonucuna ulaşılmıştır.

Çalışma sonucuna göre Türkiye'de istihdam politikası olarak uygulanan post- keynesyen yaklaşımların Kars ilindeki sonuçlarının memnuniyet verici olmadığını söylemek mümkündür. İstihdam artışı yaratmak için çalışmalar yapılmakta iken uygulanan programlarla işe yerleştirilen bireylerin bu işlerde ne kadar süre çalıştıkları, çalışma süresince katlanmak zorunda kaldıkları zorluklar kontrol mekanizmasının dışında kalmaktadır.

Ele aldığımız çalışma neticesinde Kars ilinde çalışanların bir takım zorluklar içerisinde olduğu ve birçoğunun çalıştığı işten memnun olmadığı sonucuna ulaşılmıştır. Bu memnuniyetsizlikleri ortadan kaldırmak veya etkisini azaltmak için bir takım tedbirler almak mümkündür. Gerekli görülen tedbirler şu şekilde sıralanabilir:

1. İşyerlerinde gerekli dayanışma ortamı oluşturularak çalışanların huzur ve güven içerinde işlerine devamının sağlanması gerekmektedir.

2. Emeğin saygın konumunun korunması ve yükseltilmesi için emeğe saygının aile içi eğitimlerle empoze edilmesi gerekmektedir.

3. İşverenler çalışan ücretlerini zamanında ödeme hassasiyeti göstermelidir. 
4. Ücret seviyesi asgari geçim seviyesinde ödenmeli, yetkililer asgari ücretin altında işçi çalıştıran işyerlerine gerekli yaptırımı uygulamalıdır.

5. İşyeri güvenliği ve temizliği gereken kanuni ölçülerde sağlanmalıdır. Gerekli hallerde devlet yetkilileri bu duruma müdahil olmalıdır.

6. Sigara ve alkol tüketimine ilişkin yasalara uyulup uyulmadığı denetimlerle kontrol edilmelidir.

7. SGK primi yatırmaksızın işçi çalıştıran işyerlerinin denetimi yapılmalıdır.

8. Bayan istihdamına yönelik hoşgörünün arttırılması için SGK ve İŞKUR tarafından gerekli seminerler ve söyleşiler düzenlenmeli, kadınların işgücü piyasasında aktif rol almaları sağlanmalıdır.

9. İşyeri kazalarında karşılaşılan zarar çalışan ücretine yansıtılmamalı, kazanın işin bir parçası olduğu kabullenilmelidir.

10. Fiziksel ve psikolojik tacizin önüne geçilmeli, istenmeyen bu durumun en aza indirilmesi için yetkililerce gerekli bilgilendirmeler yapılmalıdır.

11. Engelli personel çalıştırılmasına yönelik yasal hükümlere riayet edilmeli, işyerlerinde ve caddelerde engelli vatandaşların rahatça hareket edebileceği alanlar sağlanmalıdır.

12. Çocuklara yönelik istismarın önüne geçilmeli, sokaklarda mendil satan, dilenen ve çocuk olmasına rağmen kimi işlerde çalıştırılan çocukların eğitimlerini tamamlamaları için kendilerine ve ailelerine yardımcı olunmalıdır.

13. İŞKUR çalışma gerekliliği bulunan öğrencilerin iş hayatına girişini sağlamada etkin rol oynamalı, işe alınan personel haklarının da takipçisi olmalıdır.

14. Üniversite bünyesinde kısmi süreli olarak çalışan öğrenci sayısının arttırılması için gerekli bütçe ayrılmalı, bu hususta devletin rolü de fazla olmalıdır. 


\section{REFERENCES}

- AKTÜRK, Bekir (2008), "İşsizlik Sigortasına Karşılaştırmalı Bir Yaklaşım: Avrupa Birliği Ülkeleri ve Türkiye", Sakarya Üniversitesi, SBE, Yayınlanmamış Yüksek Lisans Tezi, Sakarya.

- ALPTEKİN, Erdem (2007), "Türkiye'nin Bitmeyen Derdi, Kayıt Dışı", AR\&GE Bülten, Mayıs, s, 4-12.

- ALTUNIŞIK Remzi, vd., Sosyal Bilimlerde Araştırma Yöntemleri SPSS Uygulamalı, Sakarya Yayınc1lık, Sakarya 2010, s.135.

- AYVAZ, Zerrin (1990), "Türkiye'de İstihdam ve İşsizlik Siorunları", İstanbul Üniversitesi, SBE, Yayınlanmamış Yüksek Lisans Tezi, İstanbul.

- BAĞLAR, Murat (2008), "İşsizlik-Suç İlişkisi ve Ekonomik Sonuçları", Çanakkale 18 Mart Üniversitesi, SBE, Yayınlanmamış Yüksek Lisans Tezi, Çanakkale.

- BAŞAR, Selim (2012), "Makro İktisada Giriş", Savaş Yayınevi, Ankara.

- BAYTAR, Yusuf (2006), "Kayıtdışı Ekonomi ile Mücadelede Dikey Denetim Yöntemi", Çukurova Üniversitesi, SBE, Yayınlanmamış Yüksek Lisans Tezi, Adana.

- BEKİROĞLU, Cemil (2010), "Türkiye'de İşsizlik Sorunun Çözümlenmesinde Uygulanan Ekonomi Politikalarının Analizi", Kadir Has Üniversitesi, SBE, Yayınlanmamış Yüksek Lisans Tezi, İstanbul.

- BİRINCI, A. (1998): "Nüfus Artışının Ekonomiye Yaptığı Etkiler Açısından Değerlendirilmesi Ve Türkiye'deki Yansımaları", Atatürk Üniversitesi Ziraat Fakültesi Dergisi, 29(1), ss.153-162.

- BOZDAĞLIOĞLU, E. Yasemin Uyar (2005), "Türkiye'de Uygulanan İşsizlik ve İstihdam Politikalarının Avrupa Birliği Uyum Sürecine Etkileri (1980 Sonras1)", Adnan Menderes Üniversitesi, SBE, Yayınlanmamış Yüksek Lisans Tezi, Aydın.

- $\quad$ DIINLER, Zeynel (1997), "İktisada Giriş", Ekin Yayınevi, Bursa.

- KARAKAYALI, Hüseyin (2005), "Ekonomi Kuramı", Emek Matbaacılık, Manisa.

- KASALAK, Alpaslan Murat (2007), "Avrupa Birliği'ndeki İstihdam Stratejileri ile Türkiye'deki İstihdam Stratejilerinin Ekonomik Anlamda Karşılaştırılması", Süleyman Demirel Üniversitesi, SBE, Yayınlanmamış Yüksek Lisans Tezi, Isparta.

- METIN, Şahin (2011), "Kayıt Dışı İstihdam ve Esnek Üretim Sürecinde Kadın Emeğinin Durumu: Türkiye'de Ev-Eksenli Çalışma", TC Başbakanlık Kadının Statüsü Genel Müdürlügü̈, Uzmanlık Tezi, Ankara.

- ÖCAL, Tezer (2007), "Makro İktisat", İkinci Sayfa -Arıkan Yayınları, İstanbul.

- PEKIN, Teyfik (1996), "Makro Ekonomi Para Gelir İstihdam", Bilge Basım, İzmir.

- ÜNAY, Cafer (1993), "Makro Ekonomi", Uludağ Üniversitesi Basımevi, Bursa.

- ÜNAY, Cafer (2001), Makro Ekonomi, Vipaş Yayıncılık, Bursa.

- ÜSTÜNER Baki (2008), "Sürdürülebilir Kalkınma Kapsamında Kars İlinin Ekonomik Kaynaklarının Değerlendirilmesi: Turizm Sektörü Örneği", Kafkas Üniversitesi, SBE, Yayınlanmamış Yüksek Lisans Tezi, Kars.

\section{ELEKTRONİK KAYNAKLAR}

- EKODİALOG, http://www.ekodialog.com/Konular/issizlik_istihdam_iliskisi.html.

- (22.03.2012). 
- GIDA TARIM VE HAYVANCILIK BAKANLIĞI. "Kars İli Tarımsal Yatırım Rehberi", SSubat 2013, http://www.taryat.gov.tr/haritalar/il_yatirim_rehberleri/kars.pdf (17.06.2013)

- HIŞIRLI, S. http://www.sanliurfaolay.com/yazar/3413-sanliurfa-ve-girisimcilikistihdam.htm, (21.03.2012).

- KADINA ŞIDDET http://www.egitimis.org.tr/haber-arsiv/kadina-ynelk-ddetehayir\#.VLZZ9yusXO4. (14.01.2014)

- KARS SANAYİCILER ODASI BAȘKANLIĞI. http://www.karsosb.org.tr/karsosb/kars-osb-kapasite-durumu.html. (01.12.2014)

- KARS VALİLIĞİ ÇEVRE VE ŞEHİRCILIK İL MÜDÜRLÜĞÜ. "Kars İli Çevre Durum Raporu", 2011, s.198. http://www.csb.gov.tr/db/ced/editordosya/kars_icdr2011.pdf (01.06.2013)

- KARS VALİLİĞİ, http://www.kars.gov.tr/kars_hayvancilik.htm (17.06.2013)

- KARS VALİLİĞİ, http://www.kars.gov.tr/kars_ulasim.htm (16.06.2013).

- KARS VALİLİĞİ, http://www.kars.gov.tr/kars_ulasim.htm (17.06.2013).

- MADEN TETKIT ARAMA. http://www.mta.gov.tr/v2.0/turkiye_maden/maden_potansiyel_2010/kars_madenler.pd $\mathrm{f}(03.12 .2014)$

- SENDİKA.ORG, http://www.sendika.org/2015/01/aralik-ayinda-en-az-127-isci-2014yilinda-ise-1886-isci-yasamini-yitirdi/. (14.01.2015)

- SERHAT TV HABER AJANSI, http://www.serhattv.com.tr/haber/165837/obsidyentasi-kursu-basladi.html (20.06.2013).

- SERKA, http://www.serka.gov.tr/bolgemiz/kars/kars-gezilecek-yerler-55.html (02.12.2014).

- $\quad$ SERKA, http://www.serka.org.tr/kars.asp (19.06.2013)

- SERKA. "Kars Stratejik Gelişme Raporu”, Ankara 2008, s.11-13. http://www.serka.gov.tr/store/file/common/b17a25e184e98a6f718a2640cef9d6c4.pdf (16.06.2013).

- TUIK, (2007). İşgücü, İstihdam ve İşsizlik İstatistikleri Sorularla Resmi İstatistik Dizisi 1,www.tuik.gov.tr/IcerikGetir.do?istab_id=132(21.03.2012)

- TUIK, http://tuikapp.tuik.gov.tr/hayvancilikapp/hayvancilik.zul (17.06.2013).

- TUIK, http://www.tuik.gov.tr/ilGostergeleri/iller/KARS.pdf (16.06.2013).

- TUIK, http://www.tuik.gov.tr/MetaVeri.do?tb_id=25\&ust_id=8. (24.03.2012) 